KS. JÓZEF SZYMAŃSKI* - WŁOCŁAWEK

\title{
REPRESJE CARSKIE WOBEC DUCHOWIEŃSTWA DIECEZJI KUJAWSKO-KALISKIEJ PO POWSTANIU STYCZNIOWYM
}

Problematyka powstania styczniowego badana jest od ponad 150 lat. $\mathrm{W}$ chwili kiedy zakończył się największy zryw narodowo-wyzwoleńczy Polaków przeciwko rosyjskiemu zaborcy zaczęto studiować jego dzieje. W setną rocznicę powstania ukazała się bibliografia prac o tym zbrojnym zrywie narodowym, która zawierała ponad 10 tys. pozycji ${ }^{1}$. Dla potrzeb tegoż opracowania podstawą źródłową jest przede wszystkim publikacja bpa Pawła Kubickiego Bojownicy kapłani za sprawe Kościoła i Ojczyzny w latach 1861-1915. Materiaty z urzędowych świadectw władz rosyjskich, archiwów konsystorskich, zakonnych i prywatnych ${ }^{2}$. To wielotomowe dzieło zawiera bardzo bogaty materiał dotyczący dziejów duchowieństwa pełniącego posługę na terenie Królestwa Polskiego i Litwy, tym samym diecezji kujawsko-kaliskiej. Podobnie opracowanie ks. Józefa Seweryna ${ }^{3}$ przedstawia bezpośredni udział w powstaniu duchowieństwa kujawsko-kaliskiego. Pewnym dopełnieniem podjętej problematyki, są regionalne opracowania uwzględniające wkład lokalnych środowisk, powstałe np. staraniem Włocławskiego Towarzystwa Naukowego oraz Muzeum Ziemi Kujawskiej i Dobrzyńskiej 13 kwietnia 1983 r. w ramach sesji naukowej Powstanie styczniowe na Kujawach - w 120 roczni$c e^{4}$, czy ziemi konińskiej ${ }^{5}$. Nie zachowały się niestety archiwalia prowenien-

* Ks. Józef Szymański - dr hab. historii; Instytut Historii i Politologii, Akademia Pomorska w Słupsku; e-mail: szymaj63@wp.pl

${ }^{1}$ E. Kozłowski, Bibliografia Powstania Styczniowego, Warszawa 1964, ss. 620.

${ }^{2}$ Opracował Paweł Kubicki biskup sufragan sandomierski. Część pierwsza. Dawne Królestwo Polskie. Tom I. Okólniki Rządu Rosyjskiego, kręujące wolność Kościoła, Diecezje Kielecka i Kujawsko-Kaliska, Sandomierz 1933.

${ }^{3}$ Udziat duchowieństwa diecezji kujawsko-kaliskiej w powstaniu styczniowym, Włocławek 2003.

${ }^{4}$ Z dziejów Powstania Styczniowego na Kujawach i Ziemi Dobrzyńskiej, red. S. Kalembka, Warszawa 1989.

${ }_{5}^{5}$ Ziemia Konińska w czasie powstania styczniowego 1863-1864, T. 2, Archiwalia, oprac. i komentarzem opatrzył J. Stępień, Konin 1994; Ziemia Konińska w czasie powstania styczniowe- 
cji kościelnej dotyczące wspomnianych wydarzeń. W czasie wojny w 1920 r., w wyniku ostrzału przez wojska sowieckie Włocławka, spłonęła zarówno siedziba biskupa włocławskiego jak i Archiwum Kurii Diecezjalnej we Włocławku wraz ze wszystkimi aktami. Jakkolwiek wiele archiwaliów udało się uzupełnić po przejęciu przez Archiwum Diecezjalne dawnych archiwów dekanalnych, to jednak zachowane akta praktycznie nie zawierają wiadomości o stosowanych wobec duchownych represjach ${ }^{6}$.

Zarówno M. Żywczyński ${ }^{7}$ jak i S. Kieniewicz ${ }^{8}$ byli zgodni, że nie posiadamy wyczerpującego opracowania na temat udziału księży w powstaniu. Tym bardziej, jest to konieczne, bo jak twierdził S. Kieniewicz:

Ogromna większość księży wspierała powstanie biorąc udział w organizacji na różnych szczeblach. Prawie każdy oddział miał swego kapelana, wielu z nich poniosło śmierć $\mathrm{w}$ bitwie, nawet jeśli sam ich udział $\mathrm{w}$ walce $\mathrm{z}$ bronią $\mathrm{w}$ ręku był zjawiskiem wyjątkowym. Blisko trzydziestu księży rozstrzelano lub powieszono, około stu zesłano na katorgę, paruset na zesłanie, mało która grupa zawodowa poniosła tak ciężkie straty9.

Oczekiwaniom tym, w swoich publikacjach sprostał E. Niebelski ${ }^{10}$. Udzielił on odpowiedzi na pytanie, jaki był rzeczywisty udział kleru łacińskiego w ruchu narodowym lat 1861-1864 i jaki był zakres represji wobec uczestników (dalszych losów zesłańców), szczególnie w stosunku do kapłanów diecezji lubelskiej i podlaskiej ${ }^{11}$. Według jego ustaleń, $w$ ramach represji za udział w powstaniu zesłano w sumie 549 duchownych, w tym z Litwy Białorusi i Ukrainy - 269 duchownych (234 świeckich i 35 zakonnych - w tym 2 bazylianów) oraz 2 siostry zakonne ${ }^{12}$.

go 1863-1864,. T. 3, Pamięć o 1863 roku: Historia i tradycje, J. Gulczyński, Konin 1994; Ziemia Konińska w czasie powstania styczniowego 1863-1864, T. 4 cz. 1, red. J. Stępień, Konin 1995; Ziemia Konińska w czasie powstania styczniowego 1863-1864, T. 4 cz. 2, red. J. Stępień, J. Gulczyński, Konin 1996; Ziemia Konińska w czasie powstania styczniowego 1863-1864. Losy $i$ wspomnienia popowstaniowe, T. 5, red. J. Stępień, Konin 1998; Ziemia Konińska w powstaniu styczniowym 1863-1864: praca zbiorowa wydana z okazji konferencji naukowej zorganizowanej $w 130$ rocznice Powstania Styczniowego w Ciążeniu 24-25.04.1993, red. Z. Kaczmarek, J. Stępień, Konin 1993; Z dziejów powstania styczniowego na ziemi konińskiej. Wybór zagadnień, red. A. Kijas, Konin 2013; J.S. Mujta, Z dziejów powstania styczniowego 1863-1864 na ziemi kolskiej, Konin 1998.

${ }^{6}$ W. Frątczak, Duchowieństwo dekanatu tureckiego $w$ świetle zarzadzenia bpa Aleksandra Bereśniewicza z 6 III 1884 r., „Teologia i Człowiek”, 18 (2011), s. 214.

${ }^{7}$ Kościól i duchowieństwo w powstaniu styczniowym, „Przegląd Historyczny”, 1938, s. 512525.

${ }^{8}$ Powstanie styczniowe, Warszawa 1983², s. 119, przypis 4.

${ }^{9}$ Cyt. za: Kieniewicz, Powstanie styczniowe, s. 552.

${ }^{10}$ A. Koział, Powstanie styczniowe oraz losy Polaków na Syberii w polskiej historiografii. Dorobek Eugeniusza Niebelskiego, w: Sybir. Wysiedlenia-losy-świadectwa, red. J. Ławski, S. Trzeciakowska, Ł. Zabielski, Białystok 2013, s. 129-134.

${ }^{11}$ E. Niebelski, Duchowieństwo lubelskie i podlaskie w powstaniu 1863 roku i na zesłaniu w Rosji, Lublin 2002; tenże, Nieprzejednani wrogowie Rosji: duchowieństwo lubelskie i podlaskie w powstaniu 1863 roku i na zesłaniu, Lublin 2008; tenże, Arcybiskup Zygmunt Szczęsny Feliński $w$ obronie duchownych więzionych $i$ zestanych za udziat $w$ ruchu narodowym lat 1861-1864, „Niepodległość i Pamięć”, 12/1 (21), 2005, s. 31-45.

${ }^{12}$ Cyt. za: Niebelski, Arcybiskup Zygmunt Szczęsny Feliński, s. 40; tenże, „Wiosna i jesień trwa tu krótko”. Księża zesłańcy 1863 roku w syberyjskiej Tunce, Lublin 2014, s. 19; tenże, 
$\mathrm{Z}$ archidiecezji warszawskiej było zesłanych -39 duchownych, diecezji płockiej - $32(28)^{13}$, diecezji sandomierskiej - (30) 24, augustowskiej - (19) $23^{14}$, lubelskiej - 18 (37) duchownych, podlaskiej - 17 (23), kujawsko-kaliskiej - 14' ${ }^{15}$, kieleckiej $-6^{16}$.

Za udział w powstaniu wykonano 669 wyroków śmierci, w większości przez powieszenie, w Królestwie Polskim stracono 475 osób, na Litwie - 180, na Ukrainie - dziewięć i w głębi Rosji - pięć. Na zesłanie skazano około 38.000 osób, z których ponad 20.000 poszło na Syberię, w tym 4.000 na katorgę, pozostali na osiedlenie. Początkowo miejscem zesłania dla duchownych były: Akatuia, gdzie przebywało 70 kapłanów i kleryków skazanych na katorgę, Nerczyńsk i rejon kopalń srebra wokół miasta (w 1865 r. było tam 23 więźniów kapłanów zmuszonych do ciężkiej pracy) oraz Usole, gdzie wśród 221 wymienionych z nazwiska katorżników było również 9 duchownych ${ }^{17}$. Później księży zesłańców skierowano do Tunki ${ }^{18}$.

Diecezja kujawsko-kaliska w 1863 r. była największą z diecezji w Królestwie Polskim, funkcjonowały w niej: 3 oficjałaty, 23 dekanaty, 358 parafii, kolegiata w Kaliszu, 30 klasztorów męskich i trzy żeńskie ${ }^{19}$. Liczyła wówczas 802 duchownych (422 diecezjalnych i 380 zakonnych) ${ }^{20}$. Diecezja ta obejmowała część województwa mazowieckiego z powiatem włocławskim oraz całe województwo kaliskie (powiaty: kaliski, koniński, sieradzki, piotrkowski, wieluński) ${ }^{21}$.

Duchowieństwo katolickie w Królestwie Polskim jak i w diecezji kujawsko-

Duchowieństwo lubelskie i podlaskie w powstaniu, s. 300.

${ }^{13}$ Według M. Grzybowskiego spośród ogólnej liczby duchowieństwa diecezji płockiej wynoszącej ok. 400 osób, prawie 180 duchownych było represjonowanych. Najbardziej dotkliwa kara - pozbawienie ich godności kapłańskiej, praw stanu i zesłanie do fortec katorżnych lub osiedlenie w odległych guberniach cesarstwa spotkała 22 kapłanów. Zob. M.M. Grzybowski, Duchowieństwo katolickie diecezji płockiej w okresie powstania styczniowego, ,Rocznik Towarzystwa Naukowego Płockiego", 5 (2013) s. 27.

${ }^{14}$ Według zaś opracowania W. Jemielitego z diecezji augustowskiej zesłanych było 19 duchownych. Zob. Księża diecezji augustowskiej, czyli sejneńskiej, ukarani za udziat w powstaniu styczniowym, „Roczniki Teologiczno-Kanoniczne”, 22 (1975) z. 4, s. 117-123.

${ }^{15}$ Według ks. Seweryna, zob. Udziat duchowieństwa diecezji kujawsko-kaliskiej, z diecezji kujawsko-kaliskiej zesłanych było 34 duchownych - s. 70 lub 42 - s. 71.

${ }^{16}$ Niebelski, Arcybiskup Zygmunt Szczęsny Feliński, s. 40; tenże, Duchowieństwo lubelskie i podlaskie w powstaniu, s. 299-300 (różne dane).

${ }^{17} \mathrm{~K}$. Sowa, Losy duchowieństwa polskiego zesłanego na Syberię po powstaniu styczniowym (1863-1883), „Nasza Przeszłość”, 77 (1992) s. 130.

${ }^{18} \mathrm{X}$. Ahasfer, Tunka. Opowiadanie o wsi Tunka, gdzie było na wygnaniu przeszło 150-ciu księży, oparte na wspomnieniach naocznych świadków i odnośnych dokumentach, Poznań 1914, s. 163; E. Niebelski, Autografy księży zesłanych do syberyjskiej Tunki w ramach represji po powstaniu 1863 roku, „Nasza Przeszłość”, 99 (2003) s. 417-422.

${ }^{19}$ B. Kumor, Granice metropolii i diecezji polskich (968-1939), „Archiwa, Biblioteki i Muzea Kościelne", 20 (1970) s. 375-380.

${ }^{20}$ Elenchus Cleri Saecularis ac Regularis Dioecesis Vladislaviensis seu Calissiensis, 1863, s. 47-55.

${ }^{21}$ E. Maliszewski, Organizacja powstania styczniowego, Warszawa 1925, s. 34. 
-kaliskiej reprezentowało różne postawy wobec powstania styczniowego. Sam biskup diecezji kujawsko-kaliskiej Michał Marszewski odnosił się wrogo do ruchu narodowego ${ }^{22}$. W maju $1861 \mathrm{r}$. zabronił organizowania nabożeństw patriotycznych na terenie diecezji. Polecił również odczytywać z ambon rozporządzenia władz carskich i nakazał ich przestrzeganie. Spotkało się to z oburzeniem zarówno duchowieństwa, jak i wiernych ${ }^{23}$. W czasie pobytu w Łęczycy 3 września $1861 \mathrm{r}$. hierarcha został zaatakowany przez miejscową ludność, która obrzuciła go inwektywami, a jego mieszkanie kamieniami ${ }^{24}$. Również sami duchowni, zebrani w maju 1861 r. w Zagórowie, skierowali do bpa M. Marszewskiego list, w którym napisali:

Jeśliby J.W. Pasterz podobne rozporządzenia przeciwne ustawom Kościoła świętego nadal jeszcze zechciał przysyłać, jakoś to czynił dotychczas, przyjmować ich nie możemy i nie będziemy.

Jednakże kiedy zastosowano represje wobec księży oskarżonych o głoszenie kazań patriotycznych i organizację manifestacji, biskup występował w ich obronie. Domagał się również od rządu zniesienia samowoli i nadużyć, jakie zaczęły być stosowane przez władze wojskowe, ingerujące w życie parafii poprzez żądanie wykazu nabożeństw i procesji. Przeciwny był także praktyce zwracania się przez duchownych do władz świeckich o pozwolenie na sprawowanie wszelkich obrzędów liturgicznych ${ }^{25}$.

Jesienią 1862 r. w Kaliszu, część duchowieństwa diecezji przystąpiła oficjalnie do organizacji powstańczej ${ }^{26}$. Udział księży w powstaniu ujawnił się w różnych formach, jako funkcjonariuszy Rządu Narodowego, jako kapelanów i żołnierzy, czy wreszcie jako pomocników powstania ${ }^{27}$. Wyrażał się on w duchowym wsparciu w kazaniach, które nawiązywały najczęściej do aktualnej sytuacji narodu, wyraźnie ukazując antypolskie nastawienie zaborcy, aż do zbiórki i zaopatrywania oddziałów w broń i żywność ${ }^{28}$. Niemal wszystkie manifestacje rozpoczynały się w świątyniach lub pod figurą czy krzyżem, często poprzedzane bywały słowem duszpasterza ${ }^{29}$, zaś plebanie i klasztory stały się miejscami spotkania dla organizujących walkę powstańców. Tam magazynowano broń, żywność i lekarstwa. W świątyniach odbierano przysięgę powstańczą, i przede wszystkim propagowano

${ }^{22}$ Kieniewicz, Powstanie styczniowe, s. 313.

${ }^{23}$ T. Kieloch, Włocławek $w$ czasach powstania styczniowego (1861-1864). W przeddzień powstania, w: Zdziejów Powstania Styczniowego na Kujawach i Ziemi Dobrzyńskiej, red. S. Kalembka, Warszawa 1989, s. 177; Seweryn, Udziat duchowieństwa diecezji kujawsko-kaliskiej, s. 35-37.

${ }^{24}$ E. Niebelski, Łęczycki incydent biskupa Marszewskiego 3 września 1861 roku, w: Religia, edukacja, kultura. Księga pamiątkowa dedykowana profesorowi Stanisławowi Litakowi, red. Surdacki, Lublin 2002, s. 217-222.

${ }^{25}$ P. Gołdyn, Franciszkanie w powstaniu styczniowym na ziemi konińskiej, Konin 2002, s. 10.

${ }^{26}$ H. Dylągowa, Duchowieństwo katolickie wobec sprawy narodowej (1764-1864), Lublin 1981, s. 143.

${ }^{27}$ Gołdyn, Franciszkanie w powstaniu styczniowym, s. 29-31.

${ }^{28}$ Seweryn, Udział duchowieństwa diecezji kujawsko-kaliskiej, s. 61.

${ }^{29}$ Powstanie styczniowe 1863-1864. Wrzenie. Bój. Europa. Wizje, red. S. Kalembka, Warszawa 1990, s. 427. 
ideę powstańczą ${ }^{30}$. Funkcję naczelników cywilnych powstania na terenie diecezji pełnili: ks. Wawrzyniec Centt - naczelnik województwa kaliskiego; ks. Ildefons Dębicki - naczelnik cywilny miasta Łask; ks. Franciszek Kopałczyński - naczelnik miasta Turek; ks. Władysław Klimkiewicz - naczelnik parafii Myślibórz; ks. Wiktor Kosmalski - naczelnik V okręgu powiatu konińskiego; ks. Ignacy Mosiński - naczelnik okręgowy powiatu wieluńskiego; ks. Teodor Rogoziński - naczelnik powiatu konińskiego; ks. Julian Tarnowski - naczelnik cywilny miasta Słupcy; ks. Antoni Pleszyński, paulin - naczelnik miasta Kłobuck; ks. Jan Grądzki, pijar - naczelnik miasta Radziejów ${ }^{31}$. Spośród ogólnej liczby kapłanów działających na rzecz powstania ponad $60 \%$ działało na wsiach i w małych miasteczkach. Jak zauważył ks. Seweryn najbardziej aktywna działalność patriotyczna duchowieństwa diecezjalnego była w dekanacie konińskim, kolskim, kaliskim, uniejowskim, szadkowskim i włocławskim. Spośród zaś duchowieństwa zakonnego najbardziej wyróżniali się: franciszkanie (Kalisz), kapucyni (Ląd), paulini (Jasna Góra), bernardyni, reformaci, pijarzy ${ }^{32}$. Tylko w okresie przedpowstańczym - 36 duchownych, którym udowodniono winę, poddano represjom, ponadto w czasie powstania i po jego upadku karano kapłanów za wzniecanie nastrojów patriotycznych ${ }^{33}$.

Winę uczestników walki powstańczej oceniały specjalnie powołane komisje sądowo-śledcze i sądy wojenne. Kary wymierzone za udział w powstaniu dzieliły się na główne i poprawcze. Główne skazywały na śmierć, ciężkie roboty i zsyłkę na Syberię, pozbawiały skazanych wszystkich praw obywatelskich (praw stanu). Karami poprawczymi były: zamieszkanie na Syberii, roty aresztanckie, domy poprawy, oddanie do służby wojskowej. Wszystkich sądzonych podzielono na 5 kategorii. Należący do I i II kategorii byli pozbawieni wszystkich praw stanu i wysłani na Syberie na osiedlenie lub katorgi. III kategoria skazanych była zaciągana do wojska. Skazanych zaliczanych do IV kategorii czasami wysyłano do środkowych guberni cesarstwa lub karano grzywną, zaś $\mathrm{V}$ kategorii umieszczano w fortecy w Modlinie lub innych specjalnie do tego przeznaczonych miejscach odosobnienia ${ }^{34}$.

Formy zaangażowania w powstanie egzemplifikują orzeczenia sądowe i policyjne dotyczące powstańczej działalności księży, tzn. kazania patriotyczne, przekazywanie korespondencji, ukrywanie powstańców, kolportaż odezw, ulotek powstańczych. Na tej podstawie duchownych sklasyfikowano jako:

podejrzanych o udział w powstaniu, pomagających powstańcom, głoszącym kazania patriotyczne, należących do partii powstańczej, biorących czynny udział w walce.

Wśród duchownych pełniących posługę duszpasterską na terenie diecezji kujawsko-kaliskiej, biorąc pod uwagę kapłanów diecezjalnych i z poszczególnych zakonów przedstawiało się to następująco:

\footnotetext{
${ }^{30}$ Seweryn, Udział duchowieństwa diecezji kujawsko-kaliskiej, s. 56.

${ }^{31}$ Tamże, s. 59.

32 Tamże, s. 43, 52-53.

33 Tamże, s. 44.

${ }^{34}$ Gołdyn, Franciszkanie w powstaniu styczniowym, s. 51-52.
} 
w powstaniu wzięło udział 33 duchownych (13 diecezjalnych, 8 bernardynów, 2 dominikanów, 6 paulinów, 4 reformatów);

- podejrzanych o udział w powstaniu było 36 duchownych (15 diecezjalnych, 5 augustianów, 4 dominikanów, 1 kapucyn, 5 paulinów, 3 pijarów, 3 reformatów);

- głoszących kazania było 21 duchownych (10 diecezjalnych, 3 bernardynów, 4 paulinów, 4 reformatów);

- pomagających w powstaniu było 55 duchownych (22 diecezjalnych, 3 bernardynów, 2 dominikanów, 14 franciszkanów, 2 kapucynów, 3 misjonarzy, 3 paulinów, 6 reformatów) ${ }^{35}$.

Za udział w manifestacjach i nabożeństwach skazanych zostało: 3 kapłanów na karę wygnania, 1 - na karę więzienia, 3 - na dozór policyjny;

- za przepowiadanie słowa Bożego, które nawiązywało do sytuacji społecznej narodu, skazanych zostało: 4 kapłanów na karę wygnania, 5 - na karę więzienia, 3 - na dozór policyjny, 1 - na karę grzywny;

- za prowadzenie, przewodniczenie śpiewom patriotycznym skazanych zostało: 2 kapłanów na karę wygnania, 3 - na karę więzienia;

- za zaangażowanie się bezpośrednio w agitację i okazywaną pomoc dla organizacji powstańczych skazanych zostało: 2 kapłanów na karę wygnania, 2 - na karę więzienia, 3 - na dozór policyjny, 5 - ukaranych zostało grzywną ${ }^{36}$.

Ks. S. Librowski zauważył, że dla Ojczyzny i Kościoła na ziemiach samego tylko zaboru rosyjskiego w latach 1861-1915 było represjonowanych 1731 duchownych ${ }^{37}$. Śmiercią zostało ukaranych ok. 30 duchownych, ok. 100 skazano na katorgę, a kilkuset na zesłanie ${ }^{38}$. Spośród duchowieństwa diecezji kujawsko-kaliskiej za udział w powstaniu było represjonowanych 94 duchownych:

- na katorgę łącznie skazano - 5 kapłanów; za udział czynny - 3, za pomoc powstańcom -2 ;

- na wygnanie skazano łącznie - 21 kapłanów, za udział czynny - 4, za podejrzenie udziału - 1, za kazania - 3, za pomoc powstańcom - 13;

- na osiedlenie skazano łącznie - 8 kapłanów, za udział czynny - 1 , za podejrzenie udziału - 3, za kazania - 3, za pomoc powstańcom - 3;

- na więzienie skazano łącznie - 29 kapłanów, za udział czynny - 4, za podejrzenie udziału -6 , za kazania -6 , za pomoc powstańcom -9 ;

- na dozór policyjny skazano łącznie - 16 kapłanów, za udział czynny - 5, za podejrzenie udziału -2 , za kazania -2 , za pomoc powstańcom -6 ;

- na karę grzywny skazano łącznie - 15 kapłanów, za udział czynny - 4, za podejrzenie udziału -2 , za kazania -1 , za pomoc powstańcom $-6^{39}$.

Najwyższą cenę za udział w powstaniu ,zapłaciło” 16 duchownych (3 - diecezjalnych, 9 - bernardynów, 1 - kapucyn, 1 - paulin, 2 - reformatów),

- na czasowym lub dożywotnim zesłaniu przebywało 42 (12 - diecezjalnych, 1 - augustianin, 1 - bernardyn, 1 - dominikanin, 11 - kapucynów, 1 - karmelita, 1 - misjonarz, 7 - paulinów, 2 - pijarów, 5 - reformatów),

\footnotetext{
${ }^{35}$ Seweryn, Udziat duchowieństwa diecezji kujawsko-kaliskiej, s. 61-63.

${ }^{36}$ Tamże, s. 44.

${ }^{37}$ S. L[ibrowski], Księża w walce o wolność Polski, Toruń 1939, s. 45.

${ }^{38}$ Kieniewicz, Powstanie styczniowe, s. 552.

${ }^{39}$ Seweryn, Udziat duchowieństwa diecezji kujawsko-kaliskiej, s. 70.
} 
- w więzieniach przebywało - 29 (12 diecezjalnych, 1 - bernardyn, 3 - franciszkanów, 1 - kapucyn, 8 - paulinów, 4 - reformatów) ${ }^{40}$. Jeżeli do tego dodamy ukaz carski z 8 listopada 1864 r., na mocy którego zamknięto 114 z 197 klasztorów (w tym 110 z 155 męskich) w Królestwie to dostrzeżemy skalę zniszczenia Kościoła ${ }^{41}$.

Nie wszyscy ze skazanych na zesłanie duchownych powrócili do kraju: jedni umarli $z$ wycieńczenia $i$ chorób, inni nie wytrzymali cierpienia, popadając w obłęd, jeszcze inni nie mieli do czego (i za co) wracać po latach oddalenia, niektórzy z własnej woli zostawali na Syberii wrastając w rosyjskie środowisko. Należy pamiętać, że tych, którym udało się powrócić nie witano jak bohaterów, wielu z nich zmuszonych było korzystać ze wsparcia innych, często z zapomóg i schronienia w przytuliskach Towarzystwa Wzajemnej Pomocy Sybiraków ${ }^{42}$.

$$
* * *
$$

Spośród represjonowanych kapłanów diecezji kujawsko-kaliskiej byli m.in.

Bethier Józef Ksawery Gustaw - Urodził się w 1836 r. w Kruszwicy. Po ukończeniu gimnazjum w Prusach, podjął w 1857 r. studia w Seminarium Duchownym we Włocławku. Po święceniach w 1861 r. podjął obowiązki wikariusza w Kole i następnie w Tuszynie. Za organizowanie nabożeństw o charakterze patriotycznym, został zesłany do guberni ołonieckiej. 29 kwietnia 1862 r. został ułaskawiony przez cara. Po zesłaniu, pracował w parafii Grochowy. Zmarł w 1903 r. $^{43}$

Bisławski Franciszek - Urodził się w 1826 r. Jako wikariusz w Sulejowie, w czasie powstania utrzymywał kontakty z powstańcami i ukrywał broń. W 1866 r. został aresztowany i uwięziony w cytadeli warszawskiej, ukarany grzywną 100 rubli za „nielegalne” czyny. Zmarł w $1894 \mathrm{rr}^{44}$

Borzęcki Ignacy - Urodził się 11 lipca 1824 r. Po ukończeniu seminarium włocławskiego i Akademii Duchownej Rzymsko-Katolickiej w Warszawie, w 1847 r. przyjął święcenia kapłańskie. Następnie pełnił obowiązki wikariusza przy kolegiacie w Choczu. Jako proboszcz w Koźminku ukrywał powstańca i odznaczał się nieprawomyślnością polityczną, za co, był pod „sekretnym” dozorem. Zmarł 14 stycznia 1884 r. $^{45}$

40 Tamże.

${ }^{41}$ W. Urban, Ostatni etap dziejów Kościoła w Polsce przed nowym tysiącleciem (1815-1965), Rzym 1966, s. 231.

${ }^{42}$ G. Piwnicki, Skutki powstania styczniowego, „Przegląd Polsko-Polonijny”, 4 (2/2012), s. 238.

43 Kubicki, Bojownicy kapłani za sprawę Kościoła i ojczyzny, s. 488-489, 556; Niebelski, Arcybiskup Zygmunt Szczęsny Feliński, s. 32, 35.

${ }^{44}$ Kubicki, Bojownicy kapłani za sprawę Kościoła i ojczyzny, s. 489; Seweryn, Udziat duchowieństwa diecezji kujawsko-kaliskiej, s. 79; Elenchus 1863, s. 29.

${ }^{45}$ Archiwum Diecezji Włocławskiej (dalej: ADW). Akta personalne Borzęckiego Ignacego; Kubicki, Bojownicy kapłani za sprawę Kościoła i ojczyzny, s. 490; Seweryn, Udziat duchowieństwa diecezji kujawsko-kaliskiej, s. 79; Elenchus 1863, s. 22. 
Budzyński Michał - Urodził się w 1834 r. Jako wikariusz w Zagórowie odznaczał się nieprawomyślnością polityczną, za co został skazany na zapłacenie 50 rubli kary i był pod dozorem policyjnym. Został też osadzony w areszcie w Koninie z myślą zesłania na Syberię ${ }^{46}$.

Burchaciński Feliks - Urodził się w 1822 r. Święcenia kapłańskie przyjął w 1846 r. Kanonik honorowy kaliski. Proboszcz parafii Przystajnia. Podejrzany o udział w powstaniu w charakterze funkcjonariusza Rządu Narodowego ${ }^{47}$. W 1874 r. jako proboszcz w Pęczniewie był ukarany za przekroczenie granicy pruskiej bez paszportu. Zmarł w $1883 \mathrm{rr}^{48}$

Cabański Andrzej - Urodził się w 1826 r. Święcenia kapłańskie przyjął w 1849 r. Proboszcz parafii Staw. Za utrzymanie kontaktów z powstańcami ukarany grzywną w wysokości 200 rubli i oddany po dozór policyjny ${ }^{49}$. W $1879 \mathrm{r}$. był proboszczem w Białkowie, gdzie odrestaurował świątynię. Zmarł 6 czerwca $1896 \mathrm{r}^{50}$

Centt (Cent) Wawrzyniec - Urodził się 5 sierpnia 1823 r. w Koźminku k. Kalisza. Szkołę średnią ukończył w Kaliszu. W 1841 r. wstąpił do Seminarium Duchownego we Włocławku. Po przyjęciu święceń kapłańskich w 1847 r. podjął posługę duszpasterską jako wikariusz w Widawie. Od 1860 r. był proboszczem w Sulejowie i dziekanem piotrkowskim, kanonikiem honorowym katedry włocławskiej. Od grudnia 1862 r. był naczelnikiem cywilnym woj. kaliskiego. Organizował oddziały powstańcze, dowodzony przez niego oddział zdobył broń w magazynach rządowych w Zduńskiej Woli 31 stycznia 1863 r. Podobne akcje prowadził w Łodzi, Aleksandrowie Łódzkim i Zgierzu. Aresztowany zbiegł do Francji, gdzie podjął działalność polityczną i duszpasterską wśród wychodźstwa polskiego. W 1871 r. powrócił do kraju, i przez pięć lat był kapelanem w średniej szkole rolniczej w Czernichowie, a następnie penitencjariuszem przy kościele NMP w Krakowie, nauczycielem śpiewu w seminarium duchownym, dyrektorem i katechetą szkoły sióstr klarysek. Od 1 kwietnia 1891 r. został rektorem domu księży emerytów. Zmarł 9 sierpnia 1905 r. $^{51}$.

Chodyński Stanisław Ksawery - Urodził się 4 listopada 1836 r. w Kaliszu, jako syn Feliksa i Honoraty z d. Wesołowska. Początkowo naukę pobierał w domu rodzinnym, następnie uczęszczał do Wyższej Szkoły Realnej w Kaliszu.

${ }^{46}$ Kubicki, Bojownicy kapłani za sprawe Kościoła i ojczyzny, s. 492, 556; Seweryn, Udziat duchowieństwa diecezji kujawsko-kaliskiej, s. 80.

${ }^{47}$ ADW. Akta personalne Burchacińskiego Feliksa; Seweryn, Udziat duchowieństwa diecezji kujawsko-kaliskiej, s. 80; Z.J. Małecki, I. Małecka, Ocalić od zapomnienia Kalwarię MoczalskoBugajska oraz Powstańców Styczniowych z 1863/1864 r., „Zeszyty Naukowe - Inżynieria lądowa i wodna w kształtowaniu środowiska", 8-9 (2013) s. 91.

${ }^{48}$ Kubicki, Bojownicy kapłani za sprawę Kościoła i ojczyzny, s. 562.

${ }^{49}$ ADW. Akta personalne Cabańskiego Andrzeja; Seweryn, Udziat duchowieństwa diecezji kujawsko-kaliskiej, s. 80.

${ }^{50}$ Sprawozdanie z wizyty pasterskiej, „Kronika Dyecezji Kujawsko-Kaliskiej”, 9 (1910) s. 278.

${ }^{51}$ J. Sokulski, Centt Wawrzyniec, w: Polski Stownik Biograficzny, t. 3, Kraków 1937, s. 229; Kubicki, Bojownicy kapłani za sprawę Kościoła i ojczyzny, s. 492; Seweryn, Udział duchowieństwa diecezji kujawsko-kaliskiej, s. 80. 
W 1855 r. podjął studia w Seminarium Duchownym we Włocławku. W 1860 r. przyjął święcenia kapłańskie z rąk bpa Tadeusza Łubieńskiego. Kontynuował studia teologiczne w Akademii Duchownej w Warszawie. Od 1863 r. był wikariuszem w Sieradzu. W dniu 25 lipca 1863 r. wygłosił w Warcie kazanie na pogrzebie powstańca Franciszka Zawadzkiego. Podejrzany przez władze carskie o udział $\mathrm{w}$ przygotowaniu powstania, został aresztowany i osadzony w więzieniu. Od 1866 r. pełnił funkcję profesora Seminarium Duchownego we Włocławku, gdzie wykładał biblistykę, historię Kościoła; pełnił także funkcje rektora. Ponadto w latach 1869-1882 był katechetą w gimnazjum i szkole realnej we Włocławku. W 1878 r. został proboszczem w Bronisławiu, a od $1882 \mathrm{r}$. w Wieńcu. Od 1887 r. ponownie został (do 1908 r.) profesorem seminarium; a w 1919 r. został profesorem honorowym Uniwersytetu Warszawskiego. Był kanonikiem kapituły katedralnej we Włocławku, protonotariuszem apostolskim, sędzią surogatem konsystorza włocławskiego. Zmarł 16 maja 1919 r. we Włocławku ${ }^{52}$.

Chodyński Zenon - Urodził się 4 listopada 1836 r. w Kaliszu, jako syn Feliksa i Honoraty z d. Wesołowska. Początkowo naukę pobierał w domu rodzinnym, następnie uczęszczał do Wyższej Szkoły Realnej w Kaliszu. W 1855 r. podjął studia w Seminarium Duchownym we Włocławku. W 1860 r. przyjął święcenia kapłańskie z rąk bpa Tadeusza Łubieńskiego i kontynuował studia teologiczne w Akademii Duchownej w Warszawie. Był podejrzany przez władze carskie o udział w przygotowaniu powstania, został więc aresztowany i osadzony w więzieniu. Od 1866 r. pełnił funkcję profesora w Seminarium Duchownym we Włocławku, a od 1874 r. rektora. Zmarł 16 maja 1887 r. $^{53}$.

Dąbrowski Onufry - Urodził się w 1802 r. W 1818 r. wstąpił do pijarów. Święcenia kapłańskie przyjął w 1830 r. W latach 1832-1834 pracował w kancelarii administratora diecezji kujawsko-kaliskiej. W 1834 r. został nauczycielem Szkoły Obwodowej we Włocławku. W tymże roku inkardynował się do diecezji. Był prepozytem w Nieszawie w latach 1857-1867, kanonikiem kapituły katedralnej, prałatem kustoszem w kapitule od $1861 \mathrm{r}$. Udzielał posług religijnych powstańcom. Zmarł w 1867 r. $^{54}$

Dębicki (Dembicki) Ildefons - Urodził się w 1836 r. Święcenia kapłańskie przyjął w $1858 \mathrm{r}$. i został wikariuszem w Lasku. Za organizowanie procesji patriotycznych został ukarany przez władze carskie ciężkim więzieniem. W czasie powstania pełnił funkcję naczelnika cywilnego miasta Łask. Do powstania zgłosił się na ochotnika, był kapelanem oddziału Yunga de Blenkenheima. $\mathrm{W}$ bitwie pod Brdowem dostał się do niewoli ${ }^{55}$.

${ }^{52}$ S. Librowski, Chodyński Stanisław, w: Encyklopedia Katolicka, t. 3, Lublin 1995, kol. 207; Kubicki, Bojownicy kapłani za sprawę Kościoła i ojczyzny, s. 493-495; Seweryn, Udział duchowieństwa diecezji kujawsko-kaliskiej, s. 80-81.

${ }^{53}$ S. Librowski, Chodyński Zenon, w: Encyklopedia Katolicka, t. 3, Lublin 1995, kol. 208; Kubicki, Bojownicy kapłani za sprawe Kościoła i ojczyzny, s. 493-495; Seweryn, Udziat duchowieństwa diecezji kujawsko-kaliskiej, s. 80-81.

${ }^{54}$ Seweryn, Udzial duchowieństwa diecezji kujawsko-kaliskiej, s. 81.

${ }^{55}$ Kubicki, Bojownicy kapłani za sprawę Kościoła i ojczyzny, s. 497; Seweryn, Udziat duchowieństwa diecezji kujawsko-kaliskiej, s. 81. 
Dobrowolski Lukasz - Urodził się w 1814 r. Święcenia kapłańskie przyjął w 1838 r. Był proboszcz parafii Lututów. Za ukrywanie powstańca na plebanii zapłacił 300 rubli kary. Zmarł w $1891 \mathrm{r}^{56}$

Falkiewicz Piotr - Urodził się w 1820 r. Święcenia kapłańskie przyjął w 1845 r. Był notariuszem konsystorza w Kaliszu, wikariuszem parafii św. Mikołaja w latach 1859-1866. W czasie powstania głosił podburzające kazania i był uważany przez władze carskie za głównego inicjatora rozruchów. W związku z tym został objęty dozorem policyjnym. Zmarł w $1900 \mathrm{r}^{57}$

Fiszer Michal - Urodził się w 1827 r. w Dobrzyniu. Naukę rozpoczął w ludowej szkole początkowej w Skępem i kontynuował w szkole klasztornej. W 1847 r. wstąpił do Seminarium Duchownego we Włocławku. Po przyjęciu święceń kapłańskich w 1851 r. podjął obowiązki wikariusza w Lubieniu. W 1856 r. objął probostwo w Połajewie i Broniszewie. W 1861 r. wygłosił w kilku kościołach „podburzające kazania” zachęcające do powstania i ostro występujące przeciw zaborcy. Z rozkazu namiestnika Królestwa został aresztowany i 13 listopada 1861 r. zesłany do guberni permskiej. Do kraju powrócił 5 listopada 1882 r. i osiadł w diecezji płockiej, gdzie był wikariuszem w katedrze i kapelanem biskupa ${ }^{58}$. W lipcu 1884 r. powrócił do diecezji kujawsko kaliskiej i został wikariuszem w Kamieńsku. Zmarł w 1914 r. jako rezydent w Kamieńsku ${ }^{59}$.

Głuchowski Teodor - Urodził się w 1816 r. Święcenia kapłańskie przyjął w 1841 r. Był proboszczem parafii Grocholice. Za udział w powstaniu zapłacił 300 rubli kary. Zmarł w 1897 r. $^{60}$

Grygosiński Franciszek - Urodził się w 1807 r. Był proboszczem parafii Białków. Za noszenie konfederatki zapłacił 50 rubli kary. W 1872 r. jako proboszcz parafii Kokanin za propagowanie idei niepodległościowych miał być przesunięty z probostwa na wikariat ${ }^{61}$.

Harwas Czeslaw - Urodził się 5 września 1802 r. w Uściu. Naukę pobierał w Wałczu. W 1825 r. wstąpił do klasztoru bernardynów w Skępem. Swięcenia kapłańskie przyjął 18 października 1832 r. w Płocku, z rąk bpa Konstantego Wincentego Plejewskiego. Od 1836 r. był lektorem filozofii w klasztorze bernardynów w Kaliszu. W kwietniu 1842 r. starał się o sekularyzację do diecezji. Od 1 października 1842 r. został wikariuszem w Turku, zaś w sierpniu 1844 r. wikariuszem w kolegiacie kaliskiej. Od dnia 31 października 1848 r. został proboszczem parafii Dembe, 13 czerwca 1857 r. kanonikiem kolegiaty kaliskiej, a w roku

${ }^{56}$ ADW. Akta personalne Dobrowolskiego Łukasza; Kubicki, Bojownicy kaptani za sprawe Kościoła i ojczyzny, s. 498; Seweryn, Udziat duchowieństwa diecezji kujawsko-kaliskiej, s. 81.

${ }^{57}$ ADW. Akta personalne Falkiewicza Piotra; Kubicki, Bojownicy kapłani za sprawę Kościoła $i$ ojczyzny, s. 500; Seweryn, Udziat duchowieństwa diecezji kujawsko-kaliskiej, s. 82.

${ }^{58}$ „Przegląd Katolicki”, 24 (1884) s. 395; „Przegląd Katolicki”, 31 (1884) s. 509.

${ }^{59}$ Kubicki, Bojownicy kapłani za sprawę Kościoła i ojczyzny, s. 501; Seweryn, Udział duchowieństwa diecezji kujawsko-kaliskiej, s. 82; J. Kołtuniak, Połajewo nad Gopłem. Zarys dziejów, Włocławek 2004, s. 67; Niebelski, Arcybiskup Zygmunt Szczęsny Feliński, s. 32.

${ }^{60}$ ADW. Akta personalne Głuchowskiego Teodora; Kubicki, Bojownicy kapłani za sprawe Kościoła i ojczyzny, s. 503; Seweryn, Udziat duchowieństwa diecezji kujawsko-kaliskiej, s. 82.

${ }^{61}$ Kubicki, Bojownicy kapłani za sprawę Kościoła i ojczyzny, s. 505. 
1864 dziekanem kaliskim. Podejrzewany był o przechowywanie broni ${ }^{62}$. Zmarł 29 sierpnia 1876 r. $^{63}$

Jany Kazimierz - Urodził się 3 marca 1827 r. w Kaliszu, jako syn Jakuba i Katarzyny z d. Wilczyńska. Naukę początkową pobierał u franciszkanów w Kaliszu. W 1839 r. rozpoczął naukę w szkole powiatowej. W 1843 r. rozpoczął naukę w Seminarium Duchownym we Włocławku. Po czterech latach nauki, 17 listopada 1847 r. został podsekretarzem konsystorza generalnego kaliskiego, gdzie pracował do 3 marca 1850 r. Święcenia kapłańskie przyjął 16 marca 1850 r. z rąk bpa Tadeusza Łubieńskiego. Od 7 maja 1850 r. był wikariuszem w Iwanowicach. W dniu 1 marca 1851 r. objął wikariat przy kościele filialnym w Węglewicach. W czasie powstania był proboszczem parafii Brzyków i Rychłocice. Pełnił wówczas funkcję kapelana w oddziale Makarego Drohomireckiego. Poległ 12 lutego 1863 r. podczas udzielania sakramentów św. w czasie bitwy pod Pyszkowem ${ }^{64}$.

Jaśkiewicz Józef - Urodził się w 1835 r. Święcenia kapłańskie przyjął w 1859 r. Był wikariuszem w Sieradzu. Z chwilą rozpoczęcia działań zbiegł do oddziałów powstańczych ${ }^{65}$.

Jeska Pawel - Urodził się w 1831 r. Jako proboszcz parafii Naramnice k. Wielunia za ,polityczne przestępstwa” został wywieziony przez władze carskie do guberni wiatskiej ${ }^{66}$.

Jurkiewicz Wincenty - Urodził się 8 kwietnia 1837 r. Święcenia kapłańskie przyjął w 1859 r. Był proboszczem parafii Brudzew Kaliski. Podejrzany przez władze carskie o udział w powstaniu, za przekroczenie bez paszportu granicy pruskiej został zesłany na Syberię ${ }^{67}$.

Kalinowski Roman - Urodził się w 1835 r. Był wikariuszem parafii Zadzim, później na tym samym stanowisku w Ostrowąsie. Za chodzenie w konfederatce zapłacił 10 rubli kary ${ }^{68}$.

Kaszyński Wojciech - Urodził się w 1819 r. Był proboszczem parafii Skulsk. Za wyrażanie nieprawomyślnych poglądów politycznym był pod nadzorem policyjnym $^{69}$.

Klass Franciszek Ksawery - Urodził się 28 listopada 1835 r. w Raczkowie. Po ukończeniu gimnazjum w Trzemesznie podjął studia w Seminarium Duchownym we Włocławku. Święcenia kapłańskie przyjął 12 maja 1861 r. i podjął obowiązki wikariusza w parafii Konin. Głosił kazania patriotyczne i wspierał powstańców,

${ }^{62}$ ADW. Akta personalne Harwasa Czesława; Seweryn, Udziat duchowieństwa diecezji kujawsko-kaliskiej, s. 82.

${ }^{63}$ Śp. Ks. Czestaw Harwas, „Przegląd Katolicki” 29.09.1876, Nr 39, s. 619.

${ }^{64}$ ADW. Akta personalne Jany Kazimierza; Seweryn, Udziat duchowieństwa diecezji kujawsko-kaliskiej, s. 83.

${ }^{65}$ Kubicki, Bojownicy kapłani za sprawę Kościoła i ojczyzny, s. 508; Seweryn, Udział duchowieństwa diecezji kujawsko-kaliskiej, s. 83.

${ }^{66}$ Kubicki, Bojownicy kapłani za sprawę Kościoła i ojczyzny, s. 508.

${ }^{67}$ ADW. Akta personalne Jurkiewicza Wincentego; Kubicki, Bojownicy kapłani za sprawe Kościoła i ojczyzny, s. 508; Seweryn, Udział duchowieństwa diecezji kujawsko-kaliskiej, s. 83.

${ }^{68}$ Kubicki, Bojownicy kapłani za sprawę Kościoła i ojczyzny, s. 509.

${ }^{69}$ Tamże, s. 512. 
przez co został uwięziony i zesłany do guberni archangielskiej. Od 1865 r. był proboszczem w Kawnicach ${ }^{70}$, a od 1879 r. w parafii Wielgomłyny. W 1886 r. objął parafię w Korczewie, skąd w 1910 r. został zwolniony z powodu podeszłego wieku i objął kapelanię przy przytułku kaliskim na Chmielniku. Tamże zmarł 8 marca $1913 \mathrm{r}^{71}$

Klimkiewicz Władysław - Urodził się w 1839 r. Święcenia kapłańskie przyjął w 1862 r. Będąc wikariuszem w Lubieniu głosił patriotyczne kazania. Podczas pełnienia obowiązków proboszcza w Myśliborzu przyjął nominację na rewolucyjnego naczelnika cywilnego parafii. Utrzymywał kontakty $\mathrm{z}$ dowódcami oddziałów i naczelnikami zespołu polskiej żandarmerii. Był zaangażowany w akcję powstańczą wśród ludności. Zaopatrywał powstańców w broń i odzież oraz uczestniczył w rozprawach sądów rewolucyjnych. Odbierał przysięgę od wstępujących do oddziałów. Głosił „podburzające” kazania. Czynnie zaangażowany $\mathrm{w}$ oddziałach partyzanckich, był jednym $\mathrm{z}$ dowódców oddziału walczącym w powiecie wieluńskim. W lipcu 1865 r. został aresztowany i oddany pod sąd polowo-wojenny. Na wniosek Polowego Audytorium z 8 stycznia 1866 r. naczelnik Królestwa Polskiego skazał go na zesłanie na Syberię, z pozbawieniem wszystkich praw ${ }^{72}$. W styczniu 1869 r. przebywał w Tunce ${ }^{73}$. W 1872 r. został przesiedlony do Kostromy ${ }^{74}$. Zmarł przed 1894 r.

Knapiński Pawel - Urodził się 26 stycznia 1818 r. w Godzieszach Wielkich k. Kalisza, jako syn Pawła i Franciszki. Naukę pobierał w miejscowej szkole elementarnej, a od 1836 r. w szkołach obwodowych w Kaliszu. Od 1839 r. uczył się w Seminarium Duchownym we Włocławku. Święcenia kapłańskie przyjął w 1842 r. i został wikariuszem w Pątnowie i Kłobucku. W 1855 r. został proboszczem parafii Wieniec. W dniu 1 kwietnia $1863 \mathrm{r}$. brał udział w pogrzebie siedmiu powstańców z oddziału Cieszkowskiego we wsi Chabielice. Za powyższe działanie wyrokiem sądu polowo-wojennego został pozbawiony wszelkich praw stanu i skazany na osiedlenie na Syberiii ${ }^{75}$. W styczniu 1869 r. przebywał w Tunce ${ }^{76}$, a od 1873 r. został przeniesiony do Mezenia w guberni archangielskiej ${ }^{77}$. W 1875 r. otrzymał paszport z prawem wyjazdu z Imperium. Od grudnia 1875 r. był kapelanem abpa Z. Felińskiego. W grudniu 1883 r. uzyskał zezwolenie na powrót do

70 „Przegląd Katolicki”, 52 (1875) s. 825.

${ }^{71}$ Zmarli. Ś. p. ks. Franciszek Ksawery Klass, „Kronika Dyecezyi Kujawsko-Kaliskiej”, 4 (1913) s. 118; Kubicki, Bojownicy kapłani za sprawe Kościoła i ojczyzny, s. 508; Seweryn, Udziat duchowieństwa diecezji kujawsko-kaliskiej, s. 83; Ziemia konińska, t 4, cz. 1, s. 74.

${ }^{72}$ Niebelski, Duchowieństwo lubelskie i podlaskie w powstaniu, s. 627; Kubicki, Bojownicy kaptani za sprawę Kościoła i ojczyzny, s. 513-514; Seweryn, Udział duchowieństwa diecezji kujawsko-kaliskiej, s. 62, 84.

${ }^{73}$ Ahasfer, Tunka. Opowiadanie o wsi Tunka, s. 163; Niebelski, Autografy księży zesłanych do syberyjskiej Tunki, s. 420; tenże, ,,Wiosna i jesień trwa tu krótko”, s. 131, 204.

${ }_{74}^{74}$ J.S. Pietrzak, Księża powstańcy 1863, Kraków 1916, s. 92.

${ }^{75}$ ADW. Akta personalne Knapińskiego Pawła; Seweryn, Udziat duchowieństwa diecezji kujawsko-kaliskiej, s. 84; Kubicki, Bojownicy kapłani za sprawę Kościoła i ojczyzny, s. 514-515.

${ }^{76}$ Niebelski, Autografy księży zesłanych do syberyjskiej Tunki, s. 420; Ahasfer, Tunka. Opowiadanie o wsi Tunka, s. 163.

${ }^{77}$ Pietrzak, Księża powstańcy 1863, s. 92. 
Królestwa Polskiego. Zmarł w Kłobucku, w 1885 r. ${ }^{78}$

Kobusiewicz Andrzej - Urodził się w 1819 r. Był wikariuszem parafii kolegiackiej w Kaliszu. Został aresztowany pod koniec 1863 r. i osadzony w miejscowym areszcie politycznym, za przynależność do kaliskiej organizacji powstańczej $^{79}$.

Kobyliński Piotr - Urodził się w 1814 r. Święcenia kapłańskie przyjął w 1838 r. Był proboszczem parafii Dobrzec. Brał udział w komisji rewolucyjnej zorganizowanej celem zjednoczenia włościan dla idei powstania. W czasie powstania był prezesem straży bezpieczeństwa. Pozostawał pod dozorem policyjnym. Zmarł w 1891 r. $^{80}$

Kochanowicz Wincenty - Urodził się 22 stycznia 1835 r., jako syn Jana i Franciszki z d. Wodzierodska. Do 12 roku życia naukę pobierał w szkole elementarnej we Włocławku, gdzie też kontynuował naukę w szkole realnej i podjął studia w Seminarium Duchownym. 25 stycznia 1858 r. z rąk bpa Jana M. Marszewskiego przyjął święcenia kapłańskie. Od 1 marca 1858 r. był nauczycielem w szkole elementarnej w Lubieniu. Od 1 maja 1861 r. pełnił funkcję wikariusza w parafii Uniejów, gdzie w latach 1861-1863 głosił patriotyczne kazania, za co dwukrotnie był karany aresztem. W latach $1865-1884$ był administratorem parafii Małyń. Zmarł 10 stycznia 1895 r. $^{81}$

Kolasa Ksawery - Urodził się w 1835 r. Święcenia kapłańskie przyjął w 1858 r. Był proboszczem parafii Kawnice. Za wyrażanie nieprawomyślnych poglądów politycznych został objęty nadzorem policyjnym. Za kazanie podburzające występujące przeciw zaborcy rosyjskiemu został zesłany do Koły w guberni archangielskiej. Skorzystał z amnestii i karę zamieniono mu na 300 rubli grzywny w $1896 \mathrm{r}^{82}$

Kolski Ignacy - Urodził się 3 sierpnia 1820 r. w Zagórowie, jako syn Józefa i Marianny $z$ d. Niedzielska. Nauki początkowe pobierał w domu rodzinnym, a następnie w Szkole Obwodowej w Kaliszu. 1 kwietnia 1842 r. wstąpił do Seminarium Duchownego we Włocławku. Święcenia kapłańskie przyjął w 1846 r. W okresie powstania był proboszczem parafii Kłóbka i dziekanem dekanatu kowalskiego. Tam został napadnięty i pobity przez kozaków, którzy ograbili też kościół i plebanię. Zmarł 21 kwietnia 1865 r. ${ }^{83}$

Kołodziejski Walenty - Urodził się w 1832 r. W 1856 r. przyjął świecenia kapłańskie. Był wikariuszem w Koninie. Za wygłoszenie kazania, odsiedział dwa miesiące w więzieniu w Modlinie i został oddany pod dozór poli-

${ }^{78}$ Niebelski, Arcybiskup Zygmunt Szczęsny Feliński, s. 41-42; tenże, „,Wiosna i jesień trwa tu krótko”, s. 101, 132-133, 140, 144, 146-160, 204.

${ }^{79}$ Kubicki, Bojownicy kapłani za sprawę Kościoła i ojczyzny, s. 515.

${ }^{80}$ Tamże, s. 515-516; Seweryn, Udziat duchowieństwa diecezji kujawsko-kaliskiej, s. 84.

${ }^{81}$ ADW. Akta personalne Kochanowicza Wincentego; Kubicki, Bojownicy kapłani za sprawe Kościoła i ojczyzny, s. 516; Seweryn, Udziat duchowieństwa diecezji kujawsko-kaliskiej, s. 84.

${ }^{82}$ Kubicki, Bojownicy kapłani za sprawę Kościoła i ojczyzny, s. 517.

${ }^{83}$ ADW. Akta personalne Kolskiego Ignacego; Kubicki, Bojownicy kapłani za sprawę Kościoła i ojczyzny, s. 517; Seweryn, Udział duchowieństwa diecezji kujawsko-kaliskiej, s. 85. 
cyjny na dwa lata ${ }^{84}$. Od 1869 r. był proboszczem w Walichnowach, gdzie jego staraniem w latach 1875-1878 wybudowano murowany kościół, poświęcony 9 kwietnia 1877 r. Zmarł w 1882 r.

Kopałczyński Franciszek - Urodził się w 1834 r. Był wikariuszem w Konecku. Za wykonywanie obowiązków w organizacji powstańczej, odsiedział miesiąc w kazamatach w Modlinie i został pozbawiony możliwości objęcia probostwa ${ }^{85}$.

Kosmalski Wincenty (Wiktor) - Urodził się 9 kwietnia 1808 r. W 1833 r. przyjął świecenia kapłańskie. W 1840 r. był wikariuszem w Kowalu. W roku 1849 został proboszczem w Giewartowie. W latach 1856-1868 był proboszczem w parafii Kramsk. W czasie powstania był naczelnikiem wojskowym w powiecie konińskim, za co został ukarany grzywną 300 rubli. W latach 1871-1873 był proboszczem w Dąbiu Kujawskim, gdzie zmarł i został pochowany na miejscowym cmentarzu ${ }^{86}$.

Kosta Józef - Urodził się w 1821 r. w Częstochowie. Po ukończeniu szkoły powiatowej w Wieluniu i gimnazjum w Piotrkowie wstąpił do Seminarium Duchownego we Włocławku. W 1844 r. przyjął świecenia kapłańskie i został wikariuszem w Wieluniu, następnie w Praszce i Chełmie. Od 1855 r. był proboszczem w Cielętnikach. Na uroczystościach religijnych (odpustach) manifestował swoje antyrosyjskie nastawienie. Za kazanie odpustowe w Kłomnicach 10 listopada $1861 \mathrm{r}$. został umieszczony przez władze rosyjskie w X Pawilonie Cytadeli warszawskiej, a stamtąd wywieziony do Pietrozawodzka w guberni ołonieckiej. Skorzystał z amnestii z 8 sierpnia 1862 r. i powrócił do parafii. W 1870 r. został proboszczem w Wielgomłynach, a w 1879 r. we Wróblewie ${ }^{87}$. Zmarł w $1885 \mathrm{r}$.

Krasicki Gabriel - Urodził się 6 marca 1818 r. Święcenia kapłańskie przyjął w 1842 r. Był proboszczem parafii Starokrzepice. W czasie powstania zgłosił się do oddziału powstańczego. Zginął $\mathrm{w}$ walce $\mathrm{w} 1863 \mathrm{r}^{88}$

Kurzawski Maksymilian Józef - Urodził się 18 stycznia 1825 r. w Kalinowej k. Błaszek, jako syn Franciszka i Katarzyny z d. Kolicka. Naukę pobierał w szkole powiatowej w Sieradzu, a następnie w Gimnazjum Gubernialnym w Piotrkowie Trybunalskim. Przez rok pracował przy Konsystorzu Generalnym Kaliskim. W dniu 1 września 1844 r. wstąpił do Seminarium Duchownego we Włocławku. 25 stycznia 1848 r. przyjął święcenia kapłańskie i został wikariuszem w parafii Dembe. Od 10 listopada tegoż roku pełnił funkcję wikariusza w parafii Dobrzec (Kalisz), zaś 23 sierpnia 1849 r. został przeniesiony do Konina. Od 7 listopada 1850 r. został wikariuszem w Wieluniu, a w dniu 23 lutego 1852 r. proboszczem parafii Góra. Czynnie brał udział w powsta-

${ }^{84}$ Kubicki, Bojownicy kapłani za sprawę Kościoła i ojczyzny, s. 518.

${ }^{85}$ Tamże.

${ }^{86}$ ADW. Akta personalne Kosmalskiego Wiktora; Seweryn, Udziat duchowieństwa diecezji kujawsko-kaliskiej, s. 85.

${ }^{87}$ Kubicki, Bojownicy kaptani za sprawę Kościoła i ojczyzny, s. 519; Niebelski, Arcybiskup Zygmunt Szczęsny Feliński, s. 32, 36.

${ }^{88}$ Kubicki, Bojownicy kapłani za sprawę Kościoła i ojczyzny, s. 558; Seweryn, Udziat duchowieństwa diecezji kujawsko-kaliskiej, s. 85. 
niu, głosił podburzające kazania. Został aresztowany przez władze carskie w kwietniu 1863 r. Początkowo przebywał w więzieniu w Kaliszu, pomimo wyroku skazującego „,w sołdaty”. W dniu 12 grudnia 1863 r. oddany został pod dozór policyjny. Zmarł 3 listopada 1893 r. w Górze ${ }^{89}$.

Larecki Stefan Ignacy - Urodził się 24 grudnia 1810 r., jako syn Józefa i Magdaleny z d. Markowska. Nauki początkowe pobierał w Wolborzu, od 15 września 1825 r. kontynuował u pijarów w Piotrkowie. Od września 1831 r. został aplikantem przy Komisji Wojewódzkiej w Kaliszu, a od 14 lutego 1832 r. został kancelistą etatowym. W dniu 15 września 1832 r. wstąpił do Seminarium Duchownego we Włocławku. Święcenia kapłańskie przyjął w Płocku w 1835 r. i został wikariuszem w Rzgowie. Od 14 kwietnia 1840 r. był administratorem w Stawiszynie, kanonikiem honorowym kaliskim. W latach 1860-1868 był kapelanem przy kaplicy w Strzałkowie (parafia Radomsko). Brał czynny udział w powstaniu. Po aresztowaniu ks. Mosińskiego w październiku 1863 r. został proboszczem w Dmeninie. Zmarł w 1888 r. ${ }^{90}$

Lisiecki Józef - Urodził się w 1803 r. Święcenia kapłańskie przyjął w 1829 r. Był kanonikiem katedralnym, oficjałem konsystorza kaliskiego, od 1854 r. proboszczem parafii św. Mikołaja w Kaliszu. Został aresztowany za przechowywanie i rozpowszechnianie korespondencji rewolucyjnej i ukarany grzywną 500 rubli. Był pod dozorem policji. Zmarł w 1872 r. ${ }^{91}$

Miaskowski Witold - Urodził się w 1832 r. Święcenia kapłańskie przyjął w 1860 r. Był proboszczem parafii Złotków. Walczył w oddziale Calliera. Został ranny w bitwie pod Kleczewem. Po opuszczeniu szpitala, z decyzji namiestnika kaliskiego okręgu wojennego i namiestnika Królestwa Polskiego, w dniu 8 lipca 1864 r. został skazany na wygnanie do guberni kostromskiej. Zmarł w 1866 r. w Rosji ${ }^{92}$.

Michalski Julian Adam - Urodził się w 1837 r. Święcenia kapłańskie przyjął w 1860 r. Był wikariuszem w Piotrkowie Trybunalskim. Został aresztowany 24 lipca 1863 r. jako przewodniczący żeńskiego rewolucyjnego komitetu w Piotrkowie. W dniu 26 lipca uwięziono go w Cytadeli warszawskiej, a następnie zesłano na roboty aresztanckie do guberni tambowskiej ${ }^{93}$.

Modrzejewski Damazy - Urodził się 26 listopada 1832 r. Święcenia kapłańskie przyjął w 1857 r. Od 1859 r. był wikariuszem w kolegiacie kaliskiej. Za rozpowszechnianie literatury powstańczej i udział w powstaniu został skazany na

${ }^{89}$ ADW. Akta personalne Kurzawskiego Maksymiliana; Kubicki, Bojownicy kaptani za sprawe Kościoła i ojczyzny, s. 522-523; Seweryn, Udział duchowieństwa diecezji kujawsko-kaliskiej, s. 8586; Niebelski, Arcybiskup Zygmunt Szczęsny Feliński, s. 32, 35.

${ }^{90}$ ADW. Akta personalne Lareckiego Ignacego Szczepana; Seweryn, Udziat duchowieństwa diecezji kujawsko-kaliskiej, s. 86.

${ }^{91}$ Kubicki, Bojownicy kapłani za sprawę Kościoła i ojczyzny, s. 523-524; Seweryn, Udziat duchowieństwa diecezji kujawsko-kaliskiej, s. 86.

${ }^{92}$ Kubicki, Bojownicy kaptani za sprawę Kościoła i ojczyzny, s. 527-528.

${ }^{93}$ Tamże, s. 528-529; Seweryn, Udzial duchowieństwa diecezji kujawsko-kaliskiej, s. 87. 
zesłanie do Rosji. Karę zamieniono na 200 rubli $^{94}$. Zmarł w 1864 r.

Mosiński Ignacy - proboszcz parafii Dmenin. Był również kanonikiem kapituły kolegiackiej w Kaliszu. Przed powstaniem zaangażował się w uświadamianie narodowe parafian, zachęcał ich do konspiracji i przeciwstawiania się polityce zaborcy. Głosił podburzające kazania. Odczytywał z ambony dekrety Rządu Narodowego, zakazywał wiernym płacić podatki państwowe. Rząd Narodowy powołał go na naczelnika rewolucyjnego. W dniu 20 września 1863 r. został aresztowany i osadzony w więzieniu w Radomsku. Został przewieziony do Cytadeli w Piotrkowie 25 października 1863 r. Na mocy wyroku z dnia 21 lutego 1864 r., został skazany na karę śmierci przez powieszenie za szczególnie szkodliwą działalność rewolucyjną. Wyrok wykonano 5 marca 1864 r. w Piotrkowie ${ }^{95}$.

Motylewski Jan - Urodził się w 1831 r. Święcenia kapłańskie przyjął w 1855 r. Był proboszczem parafii Ruda. Za ukrywanie broni w czasie powstania, był uwięziony przez dwa miesiące w Cytadeli warszawskiej. Od 1889 r. był proboszczem w Iwanowicach, gdzie zmarł w 1908 r. i został pochowany na miejscowym cmentarzu $^{96}$

Naraziński Ignacy - Urodził się w 1821 r. Święcenia kapłańskie przyjął w 1844 r. Był proboszczem parafii Kleczew. Wspierał powstańców m.in. dostarczał im ubrania. Za udział w powstaniu został w marcu 1864 r. skazany na wygnanie do guberni kostromskiej ${ }^{97}$. W 1876 r. przebywał w Warnawinie. W styczniu 1892 r. zezwolono mu na powrót do diecezji. Zmarł w 1896 r.98

Nejman Leopold - Urodził się w 1828 r. w Wieluniu. Święcenia kapłańskie przyjął w 1851 r. i został wikariuszem w Rząśni. W następnym roku został skazany na pokutę kanoniczną w klasztorze reformatów w Wieluniu. Na podstawie listu warszawskiego prokuratora cywilnego 15 lipca 1863 r. został aresztowany za czynny udział w powstaniu. Zmarł w 1870 r. ${ }^{99}$

Orzechowski Michał - Urodził się 9 września 1832 r. w Pyzdrach, jako syn Macieja i Rozalii z d. Baczyńska. Naukę pobierał w szkole elementarnej Ignacego Maciejewskiego w Sieradzu, a po pięciu latach kontynuował tamże w szkole powiatowej. Po ukończeniu w 1849 r., przez rok uczył się prywatnie łaciny. W latach 1851-1855 studiował w Seminarium Duchownym we Włocławku. Święcenia kapłańskie przyjął 9 września 1855 r. w Częstochowie z rąk bpa kujawsko-kaliskiego Tadeusza Łubieńskiego. Posługę duszpaster-

\footnotetext{
${ }^{94}$ ADW. Akta personalne Modrzejewskiego Damazego; Kubicki, Bojownicy kapłani za sprawe Kościoła i ojczyzny, s. 530.

${ }^{95}$ Seweryn, Udziat duchowieństwa diecezji kujawsko-kaliskiej, s. 87.

${ }^{96}$ Kubicki, Bojownicy kapłani za sprawę Kościoła i ojczyzny, s. 531; Seweryn, Udział duchowieństwa diecezji kujawsko-kaliskiej, s. 88.

${ }^{97}$ Niebelski, Duchowieństwo lubelskie i podlaskie w powstaniu, s. 627; Kubicki, Bojownicy kapłani za sprawę Kościoła i ojczyzny, s. 531.

${ }^{98}$ Niebelski, Arcybiskup Zygmunt Szczęsny Feliński, s. 43.

${ }^{99}$ W. Wlaźlak, Duchowieństwo parafii Rząśnia w okresie niewoli narodowej, „Częstochowskie Studia Teologiczne”, 34 (2006) s. 233; Seweryn, Udziat duchowieństwa diecezji kujawsko-kaliskiej, s. 88 .
} 
ską podjął jako wikariusz w Sędzinie (od 9 września 1855 r.), Bytoniu (od 25 lutego 1856 r.). Jako wikariusz parafii Lubraniec rezydował w jej filii w Zgłowiączce (od 2 kwietnia 1857 r.), gdzie wybudował świątynię. W dniu 5 stycznia 1859 r. został proboszczem parafii Błenna, gdzie wybudował kościół. Współpracował z powstańcami. Po walkach pod Brdowem, udzielał pomocy i sakramentów świętych rannym. Podczas wykonywanych czynności został napadnięty przez kozaków i przewieziony do więzienia w Kaliszu. W dniu 10 września 1881 r. został proboszczem i dziekanem w Turku, gdzie przyczynił się do powstania projektu budowy nowej świątyni. Od $1891 \mathrm{r}$. sprawował także obowiązki asesora konsystorza kaliskiego oraz egzaminatora prosynodalnego. Zmarł 30 grudnia 1912 r. ${ }^{100}$

Piasecki Andrzej - Urodził się w 1792 r. Święcenia kapłańskie przyjął w 1820 r. Był proboszczem w parafii Wierzchy. Za podburzające kazania został oddany pod dozór policyjny ${ }^{101}$. Zmarł w $1873 \mathrm{r}$.

Piekarski Aleksander - Urodził się w 1838 r. Święcenia kapłańskie przyjął w $1861 \mathrm{r}$. Był proboszczem parafii Świerczyn. Za podburzające kazania, głoszone w swojej i okolicznych parafiach, w dniu 16 lipca 1861 r. został osadzony w więzieniu we Włocławku, a następnie oddany pod dozór policyjny ${ }^{102}$. Zmarł w $1862 \mathrm{r}$.

Prus(s) Serafin - Urodził się 1 lutego 1816 r. w Trzemesznie, jako syn Wojciecha i Franciszki. Święcenia kapłańskie przyjął we Włocławku w 1840 r. Od 1852 r. był proboszczem parafii Russocice. Od 1856 r. został kanonikiem honorowym katedry lubelskiej ${ }^{103}$. Za udział w powstaniu został ukarany grzywną 100 rubli $^{104}$. Zmarł 30 sierpnia $1890 \mathrm{r}$. Został pochowany na cmentarzu w Russocicach.

Przeciechowski Wincenty - Urodził się w 1804 r. Święcenia kapłańskie przyjął w $1827 \mathrm{r}$. W latach 1830-1831 pracował jako administrator w Budzisławiu Kościelnym. Był proboszczem parafii Sędzin. Wykazywał duże zaangażowanie religijno-patriotyczne, kolportował prasę, ulotki powstańcze. Był ukarany grzywną 150 rubli. 22 lutego 1864 r. został aresztowany we Włocławku przez władze carskie za udział w manifestacjach ${ }^{105}$. Zmarł w $1882 \mathrm{r}$.

${ }^{100}$ Seweryn, Udziat duchowieństwa diecezji kujawsko-kaliskiej, s. 89; Frątczak, Duchowieństwo dekanatu tureckiego, s. 214, 231; F. Buchalski, Ś.p. Ks. Michat Orzechowski, „Kronika Dyecezji Kujawsko-Kaliskiej" 7(1913), s. 57-59.

${ }^{101}$ Seweryn, Udziat duchowieństwa diecezji kujawsko-kaliskiej, s. 89; Kubicki, Bojownicy kapłani za sprawę Kościoła i ojczyzny, s. 533.

${ }^{102}$ Kieloch, Włocławek w czasach powstania styczniowego, s. 193; Seweryn, Udział duchowieństwa diecezji kujawsko-kaliskiej, s. 89.

${ }^{103}$ Informacje z płyty nagrobnej na cmentarzu w Russocicach.

${ }^{104}$ Seweryn, Udziat duchowieństwa diecezji kujawsko-kaliskiej, s. 89; Kubicki, Bojownicy kapłani za sprawę Kościoła i ojczyzny, s. 537-538. Autor błędnie podał, że ks. Pruss był proboszczem parafii Rossoszyca.

${ }^{105}$ Kieloch, Włocławek $w$ czasach powstania styczniowego, s. 192; Seweryn, Udziat duchowieństwa diecezji kujawsko-kaliskiej, s. 89; Kubicki, Bojownicy kapłani za sprawę Kościoła i ojczyzny, s. 537-538. 
Radecki Franciszek - Urodził się w 1833 r. Święcenia kapłańskie przyjął w 1857 r. i został wikariuszem w Piotrkowie Kujawskim (do 1863 r.). Organizował zbiórki pieniężne na rzecz powstania. Był sądzony we Włocławku. Zmarł w 1895 r. ${ }^{106}$

Rogoziński Teodor - Urodził się 22 października 1822 r. w Ślesinie. Seminarium Duchowne ukończył we Włocławku, gdzie w 1845 r. przyjął święcenia kapłańskie i został wikariuszem w Koninie. W 1857 r. otrzymał prezentę od Jana Zamoyskiego na proboszcza parafii Tuliszków. W czasie powstania był rewolucyjnym naczelnikiem czwartego okręgu powiatu konińskiego, następnie całego okręgu. Utrzymywał stałe kontakty z oddziałami powstańczymi, głównie z korpusem Taczanowskiego. Zbierał środki pieniężne na wyposażenie oddziału. Na przełomie 1863/1864 został aresztowany. Wyrokiem Polowego Audytorium z dnia 10 października 1864 r. został skazany na karę śmierci. Naczelnik Królestwa Polskiego na prośbę bpa kujawsko-kaliskiego zmienił wyrok na cztery lata katorgi w fabrykach syberyjskich. Pracował w kopalni w Nerczyńsku, a od 1865 r. w warzelniach soli w Usolu, skąd wraz i innymi duchownymi został przeniesiony do Tunki. W styczniu 1869 r. pełnił tam funkcję starosty ${ }^{107}$. Po odbyciu kary, w 1874 r. zesłany do Halicza, a stamtąd do Spuska. Ok. 1883 r. pozwolono mu powrócić do kraju. Osiadł w Krakowie, gdzie był kaznodzieją i spowiednikiem sióstr wizytek. Zmarł 22 lipca 1896 r. i został pochowany na cmentarzu Rakowickim ${ }^{108}$.

Rozpędowski Mikołaj - Urodził się 10 grudnia 1808 r. w Smólku k. Warty, jako syn Kaspra i Tekli z d. Madejska. Po ukończeniu w 1826 r. elementarnej szkoły parafialnej, podjął naukę w Warcie. Od 15 września 1831 r. kontynuował naukę w szkole wydziałowej w Kaliszu. Naukę w Seminarium Duchownym we Włocławku podjął 16 września 1832 r. W dniu 6 sierpnia 1835 r. przyjął święcenia kapłańskie w Płocku z rąk bpa Konstantego Wincentego Plejewskiego i został wikariuszem w Rząśni. Od 10 września 1836 r. był wikariuszem w Łęczycy. Od 1 kwietnia 1842 r. został wikariuszem przy kościele św. Mikołaja w Kaliszu. W dniu 26 kwietnia 1844 r. został najpierw rządcą, a następnie proboszczem parafii Trąbczyn, gdzie pełnił swoje obowiązki do października 1864 r. Za udział w powstaniu miał być zesłany do Rosji ${ }^{109}$, jednak wyrok dzięki wsta-

${ }^{106}$ J. Kołtuniak, Piotrków Kujawski. Zarys dziejów miasta i parafii, Bydgoszcz 2002, s. 114, 204; Seweryn, Udział duchowieństwa diecezji kujawsko-kaliskiej, s. 89; Kieloch, Włocławek w czasach powstania styczniowego, s. 192.

107 Niebelski, Autografy księży zesłanych do syberyjskiej Tunki, s. 420; Ahasfer, Tunka. Opowiadanie o wsi Tunka, s. 120, 143, 163; Pietrzak, Księża powstańcy 1863, s. 92, 102.

${ }^{108}$ R. Bender, Rogoziński Teodor, w: Polski Stownik Biograficzny, t. 31, Warszawa-Kraków 1988-1989, s. 473; Kubicki, Bojownicy kapłani za sprawę Kościoła i ojczyzny, s. 538-539; Pietrzak, Księża powstańcy 1863, s. 92; Niebelski, Duchowieństwo lubelskie i podlaskie $w$ powstaniu, s. 628: J. Łojko, J. Stępień, Dzieje Tuliszkowa, Poznań-Konin 1995, s. 98, 100, 103, 108, 158, 221; Librowski, Księża w walce o wolność, s. 45; W. Bryliński, Parafia Św. Wita w Tuliszkowie. Dzieje i współczesność, Włocławek 2015, s. 48-50

${ }^{109} \mathrm{~W}$ aktach personalnych ks. Karkowskiego zachował się list bpa M. Marszewskiego z 6 sierpnia 1864 r.: „J.W. Namiestnik Królestwa raczył łaskawie zezwolić na pozostawienie w Kraju M. Rozpędowskiego Proboszcza w Trąbczynie, który za udział w powstaniu skazany został na zesłanie do Cesarstwa, $\mathrm{z}$ tem jednakże zastrzeżeniem, aby do innej parafii przeniesiony został ko- 
wiennictwu naczelnika wojennego oddziału kaliskiego anulowano. Następnie, podjął obowiązki proboszcza w Sadlnie i pełnił je do 1878 r. Zmarł 22 marca 1888 r. ${ }^{110}$

Różycki Walerian - Urodził się 27 stycznia 1827 r. Święcenia kapłańskie przyjął w 1854 r. Był proboszczem parafii Kliczków Mały. W czasie powstania ukrywał powstańców i głosił patriotyczne kazania, za co został skazany na osiedlenie się w Rosji ${ }^{111}$.

Rudnicki Adam - Urodził się 24 grudnia 1821 r. w Mietlicy nad Gopłem, jako syn Antoniego na Rzeczycy Jastrzębiec Rudnickiego i Michaliny z d. Jasińska Pomian. Nauki początkowe pobierał w domu rodzinnym, kontynuował w Gnieźnie, następnie $\mathrm{w}$ gimnazjum w Trzemesznie. W dniu 1 września 1843 r. wstąpił do Seminarium Duchownego we Włocławku. Święcenia kapłańskie przyjął 13 czerwca 1847 r. z rąk bpa Tadeusza Lubieńskiego i od 28 czerwca został wikariuszem w Osyjakowie. W dniu 2 czerwca 1848 r. został wikariuszem w Nieszawie i jeszcze w tym samym roku w Kowalu. Od 28 sierpnia 1849 r. pełnił ten sam urząd w Raciążku, a od 18 listopada 1851 r. w Bolesławcu. W dniu 26 stycznia 1853 r. został wikariuszem w Pajęcznie, zaś 30 września 1853 r. objął probostwo w Marzeninie. 16 listopada 1858 r. został proboszczem parafii Rajsko. W latach 1861-1863 głosił kazania podburzające wiernych, za co był więziony. Zmarł w $1888 \mathrm{r}^{112}$

Rusecki Jan - Urodził się w 1832 r. Szkołę średnią ukończył w Kaliszu. Po przyjęciu święceń kapłańskich w 1855 r., podjął obowiązki wikariusza w Piotrkowie Kujawskim (do 1859 r.). Był proboszczem parafii Borków. Władze carskie podejrzewały go o udział w powstaniu. Został aresztowany 12 lipca 1863 r., z zarzutem przejścia granicy pruskiej bez paszportu. W dniu 25 sierpnia 1866 r. skazano go na wygnanie na Syberię. Początkowo został osiedlony w Tunce ${ }^{113}$, a w 1873 r. zamieszkał w Szenkursku, w guberni archangielskiej ${ }^{114}$. Zmarł 9 września 1879 r. w Suboczu w Kurlandii ${ }^{115}$.

niecznie. Wiedząc że J.W.X. Proboszcz życzysz sobie zmiany miejsca, gotowi jesteśmy powierzyć Mu probostwo w Trąbczynie a X. Rozpędowskiego przenieść do Sadlna i tym sposobem pogodzić rzeczy i zadowolnić i jedną i drugą stronę. Wzywamy więc J.W.X. Karkowskiego aby bez żadnej straty czasu udał się do Trąbczyna, porozumiał się w tej mierze z X. Rozpędowskim a następnie przybył natychmiast do Nas do Włocławka dla dalszego załatwienia tego projektu. M. Marszewski. ADW. Akta personalne Karkowskiego Walentego Teofila.

${ }^{110}$ ADW. Akta personalne Rozpędowskiego Mikołaja; Wlaźlak, Duchowieństwo parafii Rząśnia wokresie niewoli narodowej, s. 231; Seweryn, Udziat duchowieństwa diecezji kujawsko-kaliskiej, s. 90; Kubicki, Bojownicy kapłani za sprawę Kościoła i ojczyzny, s. 539.

111 ADW. Akta personalne Różyckiego Walerego; Kubicki, Bojownicy kapłani za sprawę Kościoła i ojczyzny, s. 539.

${ }^{112}$ ADW. Akta personalne Rudnickiego Adama Józefa Jana Nepomucyna; Seweryn, Udziat duchowieństwa diecezji kujawsko-kaliskiej, s. 90; Kubicki, Bojownicy kapłani za sprawę Kościoła i ojczyzny, s. 539.

113 Niebelski, Autografy księży zesłanych do syberyjskiej Tunki, s. 420; Ahasfer, Tunka. Opowiadanie o wsi Tunka, s. 163; Kołtuniak, Piotrków Kujawski, s. 114, 204.

${ }^{114}$ Pietrzak, Księża powstańcy 1863, s. 92.

${ }^{115}$ Kubicki, Bojownicy kapłani za sprawę Kościoła i ojczyzny, s. 540; Seweryn, Udział duchowieństwa diecezji kujawsko-kaliskiej, s. 90; Niebelski, Autografy księży zesłanych do syberyjskiej 
Sandomierski Józef - Urodził się 31 marca 1833 r. w Praszce k. Wielunia, jako syn Józefa i Franciszki z d. Zawadzka. Do szkoły elementarnej uczęszczał w Piotrkowie Kujawskim, a następnie do szkoły prywatnej w Radziejowie. Naukę kontynuował $\mathrm{w}$ powiatowej szkole realnej we Włocławku, którą ukończył 27 czerwca 1849 r. Od 1 września 1857 r. studiował w Seminarium Duchownym we Włocławku. W dniu 12 maja 1861 r. przyjął święcenia kapłańskie we Włocławku, z rąk bpa Michała Marszewskiego. Jako wikariusz podjął posługę duszpasterską w Witowie (od 29 czerwca 1861 r.), Uniejowie (od 14 marca 1863 r.). Od 9 maja 1864 r. został administratorem parafii Wilamów. Pozwalał na manifestacje w kościele i śpiew pieśni patriotycznych. W dniu 10 czerwca 1882 r. został administratorem parafii Malanów. Zmarł 17 października 1884 r. ${ }^{116}$

Skupieński Klemens - Urodził się w 1813 r. w Wieluniu. Po ukończeniu miejscowej szkoły, uczył się w Szkole Wojewódzkiej w Piotrkowie Trybunalskim. W 1832 r. podjął studia w Seminarium Duchownym we Włocławku. Po przyjęciu święceń kapłańskich w 1835 r. został kapelanem bpa W.M. Tomaszewskiego, później jego sekretarzem, a następnie regensem kancelarii zadwornej. W 1838 r. został kanonikiem honorowym kaliskim, a w 1839 r. proboszczem w Kościelnej Wsi k. Kalisza. W 1845 r. został proboszczem w Tuszynie i kanonikiem kaliskim. W 1850 r. został proboszczem w Wolborzu. Dwa lata później objął funkcję asesora duchownego Komisji Rządowej Spraw Wewnętrznych i Duchownych. W 1857 r. został pronotariuszem apostolskim, w 1861 r. oficjałem piotrkowskim i prepozytem piotrkowskim, a od 1862 r. prałatem scholastykiem katedry włocławskiej. Był proboszczem parafii Piotrków Trybunalski. Przez władze carskie został określony mianem głównego prowodyra akcji powstańczej duchowieństwa diecezji kujawsko-kaliskiej. W dniu 22 stycznia 1864 r. został aresztowany i przewieziony do Warszawy, ale zwolniono go prawdopodobnie z braku dowodów. W 1867 r. został wybrany wikariuszem kapitulnym diecezji. Zmarł 3 maja 1873 r. w Piotrkowie ${ }^{117}$.

Stobiecki Józef - Urodził się 3 kwietnia 1809 r. w Kurdwanowie k. Sochaczewa, jako syn Klemensa i Tekli z d. Wolicka. Nauki początkowe do 1819 r. pobierał w domu rodzinnym, a następnie w szkole średniej w Płocku. W 1828 r. podjął studia w Seminarium Duchownym w Warszawie. Po upadku powstania listopadowego, na życzenie rodziców studia kontynuował w Seminarium Duchownym we Włocławku. Święcenia kapłańskie przyjął 15 kwietnia 1832 r. w Płocku, z rąk bpa Konstantego Wincentego Plejewskiego i został wikariuszem w Śmiłowicach. W dniu 28 września tegoż roku uzyskał zgodę władz carskich na podjęcie studiów w Rzymie. Po uzyskaniu doktoratu 7 sierpnia 1835 r. powrócił do

Tunki, s. 420 .

${ }^{116}$ Frątczak, Duchowieństwo dekanatu tureckiego, s. 237-238; Seweryn, Udziat duchowieństwa diecezji kujawsko-kaliskiej, s. 90; Kubicki, Bojownicy kapłani za sprawe Kościoła i ojczyzny, s. 541.

${ }^{117}$ W.P. Wlaźlak, Oficjałowie Konsystorza Okręgowego w Piotrkowie [Trybunalskim], ,Zeszyty Naukowe Uniwersytetu Rzeszowskiego" Prawo, 7, 53 (2009) s. 281-283 (276-287); Seweryn, Udziat duchowieństwa diecezji kujawsko-kaliskiej, s. 91; Kubicki, Bojownicy kapłani za sprawe Kościoła i ojczyzny, s. 541; Kieloch, Włocławek w czasach powstania styczniowego, s. 193; Kronika kościelna - zgon ks. prałata Skupieńskiego, „Przegląd Katolicki”, 21 (1873) s. 332. 
diecezji, aby od 21 października zostać proboszczem w Kowalu. Był kanonikiem katedry włocławskiej, radnym rady miejskiej we Włocławku. Udowodniono mu na podstawie rewizji, że brał udział w powstaniu i przechowywał korespondencję rewolucyjną. W związku z tym był sądzony w sądzie polowym we Włocławku. Zmarł w 1886 r. ${ }^{118}$

Sypniewski Józef - Urodził się w 1833 r. Święcenia kapłańskie przyjął w 1856 r. Był proboszczem parafii Modzerowo w latach 1861-1864 oraz Lubstówek (1864-1877). Ukrywał na plebanii powstańców i broń. Udzielał pomocy i sakramentów świętych po walce zbrojnej pod Brdowem. Został aresztowany i wywieziony do Konina, a następnie osadzony w Cytadeli warszawskiej ${ }^{119}$. Po zwolnieniu objął probostwo w Szadku, gdzie wybudował plebanię, a także w Pyzdrach i Licheniu ${ }^{120}$. Zmarł w $1910 \mathrm{r}$.

Ślepowroński Antoni - Urodził się w 1808 r. Święcenia kapłańskie przyjął w 1833 r. Od 1836 r. był proboszczem parafii Strońsko. Był naczelnikiem cywilnym miasta Słupcy. Brał udział w powstaniu i głosił kazania patriotyczne ${ }^{121}$. Zmarł 3 czerwca 1872 r., pochowany w Strońsku.

Święcichowski Antoni - Urodził się 24 grudnia 1809 r. w Piotrkowie Trybunalskim, jako syn Antoniego i Konstancji z d. Żubracka. Nauki początkowe pobierał w domu rodzinnym, a od września $1821 \mathrm{r}$. kontynuował w szkołach publicznych księży pijarów. 25 lutego 1831 r. został powołany do Wojska Polskiego przez Rząd rewolucyjny. Po rozwiązaniu pułku, podjął obowiązki nauczyciela domowego. 16 stycznia 1832 r. wstąpił do Seminarium Duchownego we Włocławku. Święcenia kapłańskie przyją 29 marca 1835 r. w Płocku, z rąk bpa Konstantego Wincentego Plejewskiego. Został wikariuszem w parafii Ręczno, a dwa i pół roku później parafii Koniecpol. Od 8 maja 1843 r. został proboszczem parafii Maluszyn. W czasie powstania podejmował u siebie powstańców, wspierał ich. Zmarł 21 marca 1886 r. ${ }^{122}$

Tarnawski Julian - Urodził się 11 lutego 1813 r. w Piotrkowie Kujawskim, jako syn Marcina i Marianny. Początkowo naukę pobierał w domu rodzinnym, a od $1825 \mathrm{r}$. w szkołach publicznych księży pijarów we Włocławku. W sierpniu 1830 r. wstąpił do Seminarium Duchownego we Włocławku. Nie mając wieku kanonicznego potrzebnego do przyjęcia święceń, od 12 stycznia 1834 r. pracował w Konsystorzu Kaliskim. Świecenia kapłańskie przyjął 3 maja 1835 r. w Płocku

118 ADW. Akta personalne Stobieckiego Ostoji Józefa; J. Giergielewicz, Stobiecki Ostoja Józef (1809-1886), w: Kazimierz Wielki oraz niepospolici z Kowala i okolic. Stownik biograficzny. Kalendarium, red. Z. J. Zasada, B. Ziółkowski, Włocławek-Kowal 2006, s. 219; Kieloch, Włocławek w czasach powstania styczniowego, s. 193; Seweryn, Udziat duchowieństwa diecezji kujawsko-kaliskiej, s. 91; Kubicki, Bojownicy kaptani za sprawę Kościoła i ojczyzny, s. 542-543.

${ }^{119}$ Seweryn, Udziat duchowieństwa diecezji kujawsko-kaliskiej, s. 91; Kubicki, Bojownicy kapłani za sprawę Kościoła i ojczyzny, s. 544.

${ }^{120}$ Ś.p. ks. Józef Sypniewski, „Kronika Dyecezyi Kujawsko-Kaliskiej”, 6 (1910) s. 174.

${ }^{121}$ Seweryn, Udziat duchowieństwa diecezji kujawsko-kaliskiej, s. 91; Kubicki, Bojownicy kapłani za sprawę Kościoła i ojczyzny, s. 545.

${ }^{122}$ ADW. Akta personalne Święcichowskiego Antoniego; Seweryn, Udziat duchowieństwa diecezji kujawsko-kaliskiej, s. 91. 
i został wikariuszem w Brześciu Kujawskim. W 1854 r. był proboszczem parafii Słupca, a w czasie powstania naczelnikiem cywilnym miasta Słupcy. Odbierał przysięgi powstańcze i głosił kazania patriotyczne, za co został aresztowany w kwietniu 1864 r. Zmarł 29 grudnia 1889 r. ${ }^{123}$

Towarkiewicz Antoni - Urodził się 30 maja 1814 r. w Łęczycy, jako syn Norberta i Tekli z d. Dąbrowicz. Szkołę elementarną i wydziałową ukończył w Łęczycy. Od września $1831 \mathrm{r}$. był nauczycielem prywatnym. We wrześniu 1832 r. wstąpił do Seminarium Duchownego we Włocławku. Święcenia kapłańskie przyjął 4 czerwca 1837 r. w Płocku, z rąk bpa Konstantego Wincentego Plejewskiego. Od 10 stycznia 1839 r. został administratorem w Przespolewie, zaś 1 sierpnia 1841 r. proboszczem w Charłupi Małej. Następnie był proboszczem parafii Kamieńsk. Błogosławił oddziały idące do walki. Był podejrzewany przez władze carskie o utrzymywanie kontaktów z powstańcami. Zmarł 26 lipca 1878 r. ${ }^{124}$

Wyborski Pawel - Urodził się 30 czerwca 1835 r. w Ułomiach k. Radziejowa, jako syn Marcina i Rozalii z d. Szymańska. W 1852 r. ukończył szkołę powszechną we Włocławku, a w 1856 r. podjął studia w Seminarium Duchownym we Włocławku. Święcenia kapłańskie przyjął 24 czerwca 1860 r. z rąk bpa Michała Marszewskiego i podjął posługę duszpasterską jako wikariusz parafii Kowal. Od 14 lipca 1864 r. został administratorem parafii Śmiłowice i Chocen ${ }^{125}$. W czasie powstania kolportował prasę i dostarczał broń powstańcom. Był więziony przez władze carskie we Włocławku ${ }^{126}$. Od $1886 \mathrm{r}$. administrował także parafią Kruszyn. Od 22 grudnia 1893 r. był administratorem parafii Osiek Wielki k. Koła. W lutym 1904 r. zrezygnował z probostwa i zamieszkał u kolegi (ks. Wawrzyniec Waszak) na plebani w Służewie. Zmarł 6 stycznia 1909 r. w Służewie i tam został pochowany ${ }^{127}$.

Ziarniewicz Michal - Urodził się w 1836 r. Święcenia kapłańskie przyjął w 1859 r. Był wikariuszem parafii Kłobuck. Został ukarany dozorem policyjnym za namowę powstańców do powieszenia szpiega ${ }^{128}$. Pełnił urząd naczelnika miasta podczas powstania. Był dziewięciokrotnie aresztowany i więziony m.in. w Częstochowie, Wieluniu, Piotrkowie. W 1866 r. został aresztowany i osadzony w cytadeli, z groźbą zesłania na Syberię, jednak skorzystał z amnestii. W latach 1881-1901 był proboszczem i budowniczym kościoła w Drużbicach k. Bełchatowa. Następnie objął urząd proboszcza w Truskolasach, później w Borownie k. Piotrkowa Tryb., gdzie zmarł w sierpniu 1917 r. ${ }^{129}$

${ }^{123}$ ADW. Akta personalne Tarnawskiego Juliana; Seweryn, Udziat duchowieństwa diecezji kujawsko-kaliskiej, s. 91; Kubicki, Bojownicy kapłani za sprawę Kościoła i ojczyzny, s. 545.

${ }^{124}$ ADW. Akta personalne Towarkiewicza Antoniego; Seweryn, Udziat duchowieństwa diecezji kujawsko-kaliskiej, s. 92.

${ }^{125}$ Zmarli. Ks. Pawet Wyborski, „Kronika Dyecezyi Kujawsko-Kaliskiej”, 1(1909), s. 17.

${ }^{126}$ Seweryn, Udziat duchowieństwa diecezji kujawsko-kaliskiej, s. 92.

${ }^{127}$ A. Ciechalski, Wyborski Pawet, w: Kazimierz Wielki oraz niepospolici z Kowala i okolic. Stownik biograficzny. Kalendarium, red. Z. J. Zasada, B. Ziółkowski, Włocławek-Kowal 2006, s. $252-253$.

${ }^{128}$ Kubicki, Bojownicy kapłani za sprawę Kościoła i ojczyzny, s. 551; Seweryn, Udziat duchowieństwa diecezji kujawsko-kaliskiej, s. 92.

${ }^{129}$ Ś.p. ks. Michat Ziarniewicz, ,Kurjer Warszawski” Pismo poranne. 4 sierpnia 1917 r. Nr. 213, s. 2. 
Zygmuntowicz Antoni Barnaba - Urodził się 11 czerwca 1817 r., jako syn Jana i Marianny z d. Kowalewska. Szkołę gimnazjalną ukończył w Trzemesznie. W 1837 r. wstąpił do Seminarium Duchownego we Włocławku. W lipcu 1840 r. przyjął świecenia kapłańskie z rąk bpa Józefa Joachima Goldtmanna i został wikariuszem w Nieszawie. Był proboszczem parafii Przyrów. Pełnił obowiązki skarbnika w organizacji powstańczej (według władz carskich jawnie i fanatycznie sympatyzował z powstaniem). Zmarł 26 stycznia 1891 r. ${ }^{130}$

Żmijewski Feliks - Urodził się w 1810 r., jako syn Jana i Salomei. Nauki pobierał w Żurominie. W 1827 r. wstąił do Seminarium Duchownego w Warszawie. Święcenia kapłańskie przyjął w 1834 r. i podjął obowiązki profesora w Seminarium Duchownym w Płocku. W dwa lata później zaczął wykładać w Seminarium Duchownym we Włocławku. Po trzech latach pracy w seminarium, w 1839 r. został administratorem w Osięcinach, a następnie po kolejnych trzech latach, w 1842 r. został administratorem w Kościelnej Wsi. W 1850 r. został proboszczem parafii Ostrowąs. Za głoszenie kazań patriotycznych został aresztowany we Włocławku 6 kwietnia 1863 r. Zmarł 13 stycznia 1866 r. ${ }^{131}$

Słowa kluczowe: powstanie styczniowe, rok 1863, duchowieństwo katolickie, diecezja kujawsko-kaliska.

\section{BIBLIOGRAFIA}

\section{Źródła}

Archiwum Diecezji Włocławskiej

Akta personalne Borzęckiego Ignacego.

Akta personalne Burchacińskiego Feliksa.

Akta personalne Cabańskiego Andrzeja.

Akta personalne Dobrowolskiego Łukasza.

Akta personalne Falkiewicza Piotra.

Akta personalne Głuchowskiego Teodora.

Akta personalne Harwasa Czesława.

Akta personalne Jany Kazimierza.

Akta personalne Jurkiewicza Wincentego.

Akta personalne Knapińskiego Pawła.

Akta personalne Kochanowicza Wincentego.

Akta personalne Kolskiego Ignacego.

Akta personalne Kosmalskiego Wiktora.

Akta personalne Kurzawskiego Maksymiliana.

Akta personalne Lareckiego Ignacego Szczepana.

${ }^{130}$ ADW. Akta personalne Zygmuntowicza Antoniego Barnaby; Kubicki, Bojownicy kapłani za sprawę Kościoła i ojczyzny, s. 552-553; Seweryn, Udział duchowieństwa diecezji kujawsko-kaliskiej, s. 92.

${ }^{131}$ ADW. Akta personalne Żmijewskiego Feliksa; Kieloch, Włocławek w czasach powstania styczniowego, s. 194; Seweryn, Udziat duchowieństwa diecezji kujawsko-kaliskiej, s. 93. 
Akta personalne Modrzejewskiego Damazego.

Akta personalne Rozpędowskiego Mikołaja;

Akta personalne Różyckiego Walerego.

Akta personalne Rudnickiego Adama Józefa Jana Nepomucyna.

Akta personalne Stobieckiego Ostoji Józefa;

Akta personalne Święcichowskiego Antoniego.

Akta personalne Tarnowskiego Juliana.

Akta personalne Towarkiewicza Antoniego.

Akta personalne Zygmuntowicza Antoniego Barnaby.

Akta personalne Żmijewskiego Feliksa.

\section{Źródla drukowane}

Elenchus Cleri Saecularis ac Regularis Dioecesis Vladislaviensis seu Calissiensis, 1863.

\section{Opracowania}

Ahasfer X., Tunka. Opowiadanie o wsi Tunka, gdzie było na wygnaniu przeszło 150-ciu księży, oparte na wspomnieniach naocznych świadków i odnośnych dokumentach, Poznań 1914.

Bender R., Rogoziński Teodor, w: Polski Słownik Biograficzny, t. 3, Warszawa-Kraków 1988-1989, kol. 473.

Bojownicy kapłani za sprawę Kościoła i Ojczyzny w latach 1861-1915. Materiały z urzędowych świadectw władz rosyjskich, archiwów konsystorskich, zakonnych i prywatnych. Opracował Paweł Kubicki biskup sufragan sandomierski. Część pierwsza. Dawne Królestwo Polskie. Tom I. Okólniki Rządu Rosyjskiego, krępujące wolność Kościoła, Diecezje Kielecka i Kujawsko-Kaliska, Sandomierz 1933.

Buchalski F., Ś.p. Ks. Michał Orzechowski, „Kronika Dyecezji Kujawsko-Kaliskiej”, 7 (1913) s. 57-59.

Ciechalski A., Wyborski Paweł, w: Kazimierz Wielki oraz niepospolici z Kowala i okolic. Słownik biograficzny. Kalendarium, red. Z.J. Zasada, B. Ziółkowski, WłocławekKowal 2006, s. 252-253.

Dylągowa H., Duchowieństwo katolickie wobec sprawy narodowej (1764-1864), Lublin 1981.

Giergielewicz J., Stobiecki Ostoja Józef (1809-1886), w: Kazimierz Wielki oraz niepospolici z Kowala i okolic. Słownik biograficzny. Kalendarium, red. Z.J. Zasada, B. Ziółkowski, Włocławek-Kowal 2006, s. 219.

Frątczak W., Duchowieństwo dekanatu tureckiego w świetle zarządzenia bpa Aleksandra Bereśniewicza z 6 III 1884 r., „Teologia i Człowiek”, 18 (2011) s. 213-246.

Gołdyn P., Franciszkanie w powstaniu styczniowym na ziemi konińskiej, Konin 2002.

Grzybowski M.M., Duchowieństwo katolickie diecezji płockiej w okresie powstania styczniowego, „Rocznik Towarzystwa Naukowego Płockiego”, 5 (2013) s. 25-42.

Jemielity W., Księża diecezji augustowskiej, czyli sejneńskiej, ukarani za udział w powstaniu styczniowym, „Roczniki Teologiczno-Kanoniczne”, 22 (1975) z. 4, s. 117123.

Kieloch T., Włocławek w czasach powstania styczniowego (1861-1864). W przeddzień powstania, w: Z dziejów Powstania Styczniowego na Kujawach i Ziemi Dobrzyńskiej, red. S. Kalembka, Warszawa 1989.

Kieniewicz S., Powstanie styczniowe, Warszawa $1983^{2}$.

Kołtuniak J., Piotrków Kujawski. Zarys dziejów miasta i parafii, Bydgoszcz 2002.

Kołtuniak J., Połajewo nad Gopłem. Zarys dziejów, Włocławek 2004. 
Koział A., Powstanie styczniowe oraz losy Polaków na Syberii w polskiej historiografii. Dorobek Eugeniusza Niebelskiego, w: Sybir. Wysiedlenia-losy-świadectwa, red. J. Ławski, S. Trzeciakowska, Ł. Zabielski, Białystok 2013, s. 129-134.

Kozłowski E., Bibliografia Powstania Styczniowego, Warszawa 1964, ss. 620.

Kronika kościelna - zgon ks. prałata Skupieńskiego, „Przegląd Katolicki”, 21 (1873) s. 332.

Kumor B., Granice metropolii i diecezji polskich (968-1939), „Archiwa, Biblioteki i Muzea Kościelne”, 20 (1970) s. 253-374.

Librowski S., Chodyński Stanisław, w: Encyklopedia Katolicka, t. 3, Lublin 1995, k. 207.

Librowski S., Chodyński Zenon, w: Encyklopedia Katolicka, t. 3, Lublin 1995, k. 208.

L[ibrowski] S., Księża w walce o wolność Polski, Toruń 1939.

Łojko J., Stępień J., Dzieje Tuliszkowa, Poznań-Konin 1995.

Maliszewski E., Organizacja powstania styczniowego, Warszawa 1925.

Małecki Z.J. Małecka I., Ocalić od zapomnienia Kalwarię Moczalsko-Bugajską oraz Powstańców Styczniowych z 1863/1864 r., „Zeszyty Naukowe - Inżynieria lądowa i wodna w kształtowaniu środowiska", 8-9 (2013) s. 83-112.

Mujta J.S., Z dziejów powstania styczniowego 1863-1864 na ziemi kolskiej, Konin 1998.

Niebelski E., Arcybiskup Zygmunt Szczęsny Feliński w obronie duchownych więzionych i zesłanych za udział w ruchu narodowym lat 1861-1864, „Niepodległość i Pamięć” 12/1 (21), 2005, s. 31-45.

Niebelski E., Autografy księży zesłanych do syberyjskiej Tunki w ramach represji po powstaniu 1863 roku, ,Nasza Przeszłość”, 99 (2003) s. 417-422.

Niebelski E., Duchowieństwo lubelskie i podlaskie w powstaniu 1863 roku i na zesłaniu w Rosji, Lublin 2002.

Niebelski E., Łęczycki incydent biskupa Marszewskiego 3 września 1861 roku, w: Religia, edukacja, kultura. Księga pamiątkowa dedykowana profesorowi Stanisławowi Litakowi, red. M. Surdacki, Lublin 2002, s. 217-222.

Niebelski E., Nieprzejednani wrogowie Rosji: duchowieństwo lubelskie i podlaskie w powstaniu 1863 roku i na zesłaniu, Lublin 2008.

Niebelski E., „Wiosna i jesień trwa tu krótko”. Księża zesłańcy 1863 roku w syberyjskiej Tunce, Lublin 2014.

Pietrzak J.S., Księża powstańcy 1863, Kraków 1916.

Piwnicki G., Skutki powstania styczniowego, „Przegląd Polsko-Polonijny”, 4/2 (2012) s. 231-250.

Powstanie styczniowe 1863-1864. Wrzenie. Bój. Europa. Wizje, red. S. Kalembka, Warszawa 1990.

Seweryn J. Ks., Udział duchowieństwa diecezji kujawsko-kaliskiej w powstaniu styczniowym, Włocławek 2003.

Sokulski J., Centt Wawrzyniec, w: Polski Słownik Biograficzny, t. 3, Kraków 1937, s. 229.

Sowa K., Losy duchowieństwa polskiego zesłanego na Syberię po powstaniu styczniowym (1863-1883), „Nasza Przeszłość”, 77 (1992) s. 123-164.

Sprawozdanie z wizyty pasterskiej, „Kronika Dyecezji Kujawsko-Kaliskiej”, 9 (1910), s. 278.

Ś.p. ks. Józef Sypniewski, „Kronika Dyecezyi Kujawsko-Kaliskiej”, 6 (1910) s. 174.

Ś.p. ks. Michał Ziarniewicz, „Kurjer Warszawski” Pismo poranne. 4 sierpnia 1917 r. Nr. 213, s. 2.

Śp. Ks. Czesław Harwas, „Przegląd Katolicki”, 29.09.1876, Nr 39, s. 619.

Urban W., Ostatni etap dziejów Kościoła w Polsce przed nowym tysiącleciem (18151965), Rzym 1966. 
Wlaźlak W., Duchowieństwo parafii Rząśnia w okresie niewoli narodowej, „Częstochowskie Studia Teologiczne”, 34 (2006) s. 227-238.

Wlaźlak W.P., Oficjałowie Konsystorza Okręgowego w Piotrkowie [Trybunalskim], „Zeszyty Naukowe Uniwersytetu Rzeszowskiego” Prawo 7, 53 (2009) s. 276-287.

Ziemia konińska w czasie powstania styczniowego 1863-1864, T. 2. Archiwalia, oprac. i komentarzem opatrzył J. Stępień, Konin 1994.

Ziemia Konińska w czasie powstania styczniowego 1863-1864. T. 3, Pamięć o 1863 roku: Historia i tradycje, red. J. Gulczyński, Konin 1994.

Ziemia Konińska w czasie powstania styczniowego 1863-1864, red. J. Stępień, T. 4 cz. 1, Konin 1995.

Ziemia Konińska w czasie powstania styczniowego 1863-1864, red. J. Stępień, J. Gulczyński, T. 4 cz. 2, Konin 1996.

Ziemia Konińska w czasie powstania styczniowego 1863-1864. Losy i wspomnienia popowstaniowe, red. J. Stępień, T. 5, Konin 1998.

Ziemia Konińska w powstaniu styczniowym 1863-1864: praca zbiorowa wydana z okazji konferencji naukowej zorganizowanej w 130 rocznicę Powstania Styczniowego w Ciążeniu 24-25.04.1993, red. Z. Kaczmarek, J. Stępień, Konin 1993.

Z dziejów Powstania Styczniowego na Kujawach i Ziemi Dobrzyńskiej, red. S. Kalembka, Warszawa 1989.

Z dziejów powstania styczniowego na ziemi konińskiej. Wybór zagadnień, red. A. Kijas, Konin 2013.

Zmarli. Ks. Paweł Wyborski, „Kronika Dyecezyi Kujawsko-Kaliskiej”, 1 (1909) s. 17.

Żywczyński M., Kościół i duchowieństwo w powstaniu styczniowym, „Przegląd Historyczny", 1938, s. 512-525.

\title{
TSARIST REPRESSION AGAINST THE CLERGY OF THE DIOCESE OF KUJAWY AND KALISZ AFTER THE JANUARY UPRISING
}

\begin{abstract}
Summary
All social strata of the Poles both from the Kingdom of Poland, Lithuania and Belarus took part in the national uprising in 1863 . The Catholic diocesan and monastic clergy also joined this extraordinary uprising. In the Diocese of Kujawy and Kalisz, 94 out of 422 priests were directly repressed in various ways for their patriotic and national activities. Many of them were sentenced to hard labour in Siberia, to settlement in distant regions of the empire, imprisonment, fines and surveillance. This repression hampered the realization of the mission of the Church, but did not break its will and spirit in the struggle for the rights of the Nation.
\end{abstract}

Keywords: the January Uprising, the year 1863, the Catholic clergy, the Diocese of Kujawy and Kalisz 